Portland State University

PDXScholar

5-10-1988

\title{
Analysis of Error Type, Source, and Gravity in the Writing of Arabic ESL Students in U.S.A. Colleges
}

Fadel Mohammed Na'im Bader

Portland State University

Follow this and additional works at: https://pdxscholar.library.pdx.edu/open_access_etds

Part of the Bilingual, Multilingual, and Multicultural Education Commons, and the English Language and Literature Commons

Let us know how access to this document benefits you.

\section{Recommended Citation}

Bader, Fadel Mohammed Na'im, "Analysis of Error Type, Source, and Gravity in the Writing of Arabic ESL Students in U.S.A. Colleges" (1988). Dissertations and Theses. Paper 3753.

https://doi.org/10.15760/etd.5637

This Thesis is brought to you for free and open access. It has been accepted for inclusion in Dissertations and Theses by an authorized administrator of PDXScholar. Please contact us if we can make this document more accessible: pdxscholar@pdx.edu. 
AN ABSTRACT OF THE THESIS OF Fadel Mohammad Na'im Bader for the Master of Arts in English (TESOL) presented May 10, 1988.

Title: An Analysis of Error Type, Source, and Gravity In the Writing of Arabic ESL Students In U.S.A. Colleges.

APPROVED BY MEMBERS OF THE THESIS COMMITTEE:

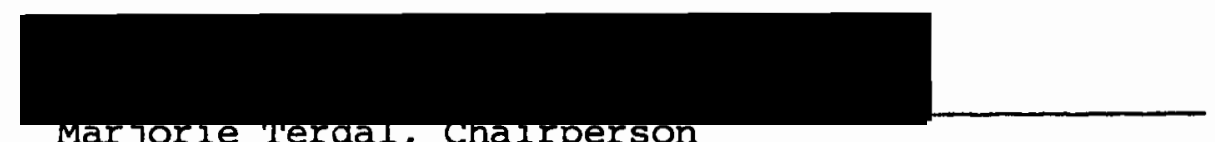

Marjorle rerdal, chairperson

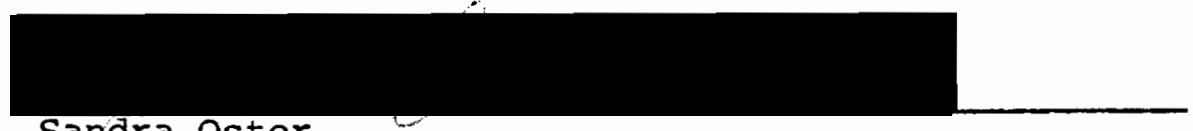

Sandra Oster

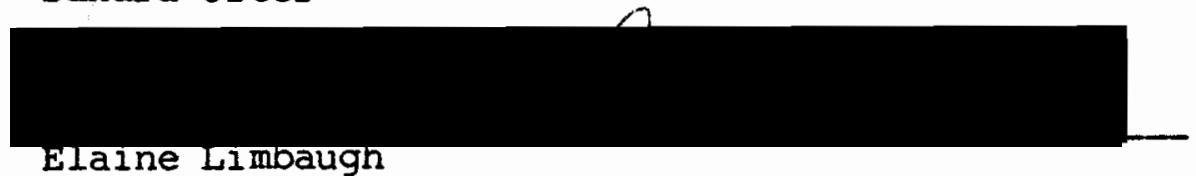

Elaine Limbaugh

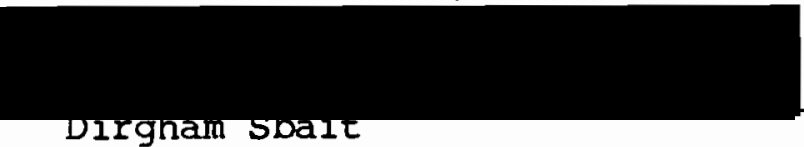

Dirghan start

The purpose of this study is to determine the type, possible source and gravity of errors found in the Test of Written English and Placement Tests compositions written by native speakers of Arabic at college level. The first part of the study is an error analysis designed to reveal the types of errors that are most frequently made by Arab students at college level. The sources of these errors are explained according to Richards' classification 
of errors as inter- and intralingual (1971). Seven types of errors are identified under interlingual category: articles, prepositions, the copula, embedded questions, pronoun retention, semantic and stylistic errors. Intralingual errors included errors in overgeneralization and ignorance of rule restriction.

The second part of the study is designed to reveal the types of errors made by Arab learners of English that affect the native speaker's understanding of the written text. Twenty grammatically deviant passages and ten semantically deviant ones make up a questionnaire that was designed to measure the effect of different types of errors on cominunication. 


\title{
ANALYSIS OF ERROR TYPE, SOURCE, AND GRAVITY \\ IN THE WRITING OF ARABIC ESL STUDENTS IN U.S.A. COLLEGES
}

\section{by}

FADEL MOHAMMAD NA'IM BADER

\author{
A thesis submitted in partial fulfillment \\ of the requirement for the degree of \\ MASTER OF ARTS \\ in \\ ENGLISH (TESOL)
}

Portland State University

1988 
TO THE OFEICE OF GRADUATE STUDIES:

The members of the Committee approve the thesis of Fadel Mohammad Na'im Bader presented May 10, 1988.

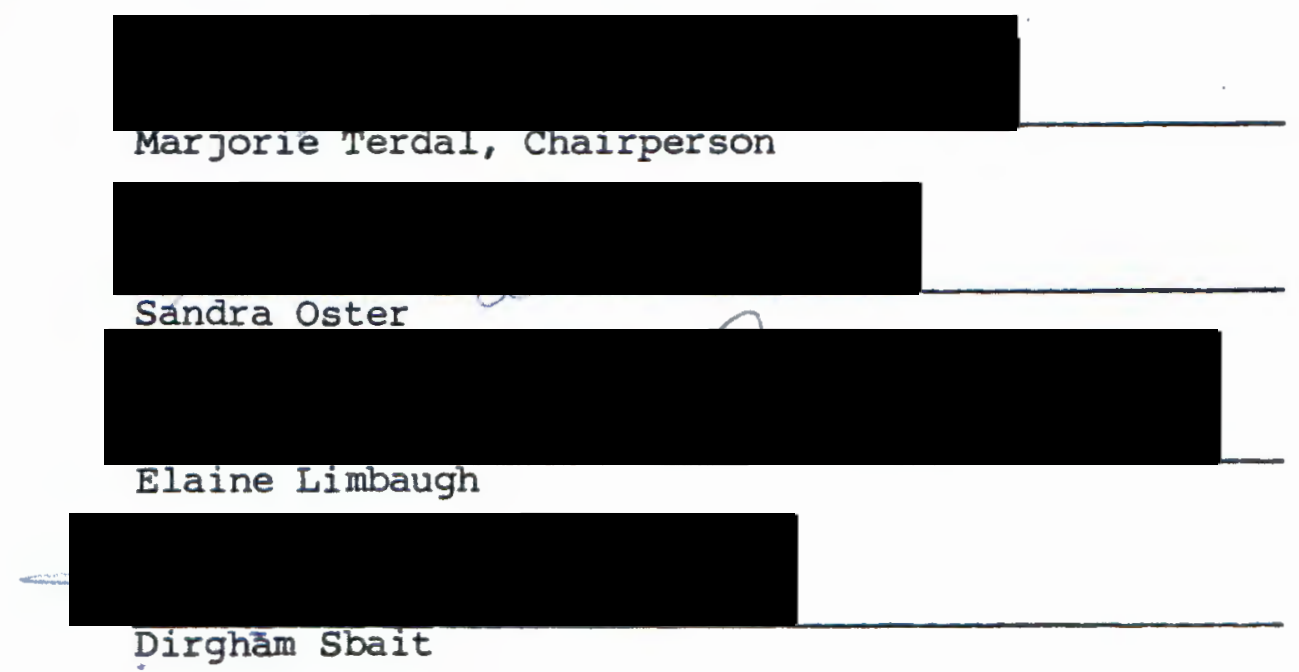

APPROVED:
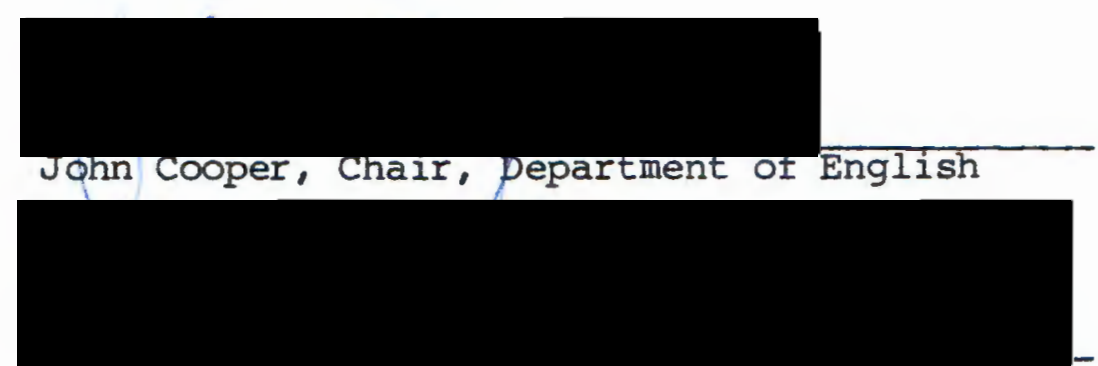

Bernard Ross, Vice provost for Graduate studies 


\section{DEDICATION}

To my father, MOHAMMAD NA'IM and my mother, MUSIRAH.

Thanks for your love, support, and encouragement. You are wonderful parents.

Your son,

Fadel Bader 


\section{ACKNOWLEDGEMENTS}

Thinking is existence. Writing is existence in existence. Thoughts vanish if the process of writing is not to preserve them; though, certainly, not all thoughts are worthy of preservation. Preserving thoughts by writing a thesis is a struggle with one's own existence; this is true of my experience. Yet when it is finished, it is one of the greatest accomplishments.

To claim that I have finished this study without anybody's help would be selfish. Therefore, I would like to extend my deep thanks and gratitude to Dr. Marjorie Terdal for her supervision, guidance, comments and feedback throughout the whole study. I am also greatful to Dr. Naguib Greis, Director of the ESL Department at PSU, for his invaluable comments on an earlier version of this study. I wish to acknowledge my gratitude to Mrs. Lori Goolsbey for the time and effort she spent in typing this thesis. Finally, I would like to extend my deep thanks and gratitude to my host family, Mr. and Mrs. Ted and Joan Baker, for their support, encouragement, and for putting up with my studying habits!! 
TABLE OF CONTENTS

PAGE

DEDICATION . . . . . . . . . . . . . . . . . . . . . i ii ACKNOWLEDGEMENTS • . . . . . . . . . . . . . . . . . . iv LIST OF TABLES • • . . . . . . . . . . . . . . . . . vii LIST OF FIGURES . . . . . . . . . . . . . . . . . . viii CHAPTER

I INTRODUCTION..$\cdot$. . . . . . . . . . . . . 1 Research Questions . . . . . . . . . 4 Summary . . . . . . . . . . . . 6

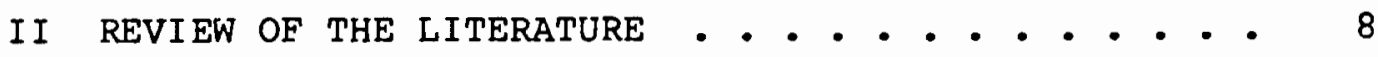
Contrastive Analysis . . . . . . . . 8 Error Analysis . . . . . . . . . . 12 Error Gravity . . . . . . . . . . . 14 Observations on Some Features in the Arabic Language and Their Counterparts in English . 16

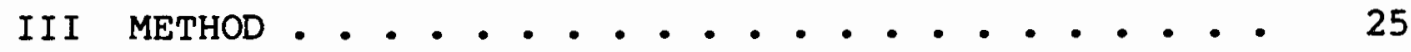

Subjects • . • . • . . . . . . . . 25

Research Design . . . . . . . . . . 26

IV INTERLINGUAL AND INTRALINGUAL ERRORS IN ARAB ESL STUDENTS' ENGLISH COMPOSITIONS • • • • • • • 30

Interlingual Errors . . . . . . . . . 30

Articles

Prepositions

The Copula

Embedded Questions

Pronoun Retention 
PAGE

Semantic Errors

Stylistic Errors

Intralingual Errors . . . . - . . . . •

Overgeneralization

Ignorance of Rule Restrictions (Exceptions)/

Incomplete Application of Rules

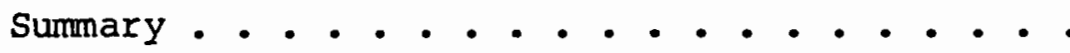

CHAPTER

V Communicative Error Evaluation . . . . . . . . 54

Summary ................. 61

VI PEDAGOGICAL IMPLICATIONS AND SUGGESTIONS . . • • 63

Sumary .. . . . . . . . . . . 63

Conclusion .. . . . . . . . . 65

BIBLIOGRAPHY • • • • • • • • • • • • • • • • 67

APPENDICES

A - Abbreviations . . . . . . . . . . . 70

B - Sample of Inter- and Intralingual Errors . . . . 71

C - Reaction to ESL Students' Writing . . . . . . 73

D - Total Number of Choices on the 4-point Scale, Average and Standard Deviation for the

Groups of Judges: Freshmen, TESL, Arabs . . 76 


\section{LIST OE TABLES}

TABLE

PAGE

I The Relationship Between Types and Sources of

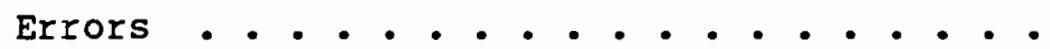

II Total Weighted Scores of Errors . . . . . .

II Chi Square Values for Grammatical vs. Semantic Errors ..................

IV Chi Square Values for All Types of Errors. . . 


\section{LIST OF FIGURES}

1. Total Weighted Scores of Grammatical and Semantic Errors on the Two Scales, Intelligibility and Acceptability . . . . 


\section{CHAPTER I}

\section{INTRODUCTION}

The aim of this research is to determine the type, possible source and gravity of errors found in the Test of written English and Placement Test compositions written by native speakers of Arabic at college level. The nature of the research is an Error Analysis (EA) of certain types of errors in the data under investigation.

The first part of the study is designed to reveal the types of errors that are most frequently made by Arab students at college level. It will also explain sources of these errors according to Richards' classification of errors as inter- and intralingual (1971).

The second part of the study is designed to reveal the types of errors made by Arab learners of English which affect the native speaker's understanding of the meaning of the written text. It is hoped that the results of this study will help determine the types of errors that deserve the ESL teacher's attention and correction in the ESL classroom. (Appendix A includes a list of the abbreviations used in this thesis and their full terminology).

Learning a foreign or a second language is by no means an easy task. Many linguists and educators all over the world are trying to understand the nature of foreign or second language 
acquisition. These linguists and educators have conducted research particularly in the second half of this century, in an attempt to understand and diagnose the problems associated with second language acquisition. As a result of their investigations, a considerable number of theories have appeared in the literature of second language learning. The primary concern of these theories is to develop the different language skills for ESL students through effective instruction with focus on learning skills and strategies. The four basic language skills that the literature of these theories has dealt with are listening, speaking, reading, and writing.

Many educators regard writing skill as a by-product of other skills, namely listening and speaking (Weaver 1979). But the importance of teaching writing in the English as a Second Language classroom should not be minimized since the students will need this skill. Therefore, writing skills should be given more time in ESL classes. According to Arapoff (1969), writing is not a mere representation of speech, but a process whereby the learner has to know not only "how to use orthographic symbols, but primarily how to select and organize experience according to a certain purpose" (33). Therefore, writing requires certain skills. These skills present themselves in the unity, coherence and logical development of ideas which are at the heart of any effective and meaningful writing.

As an ESL teacher with some knowledge and experience in the teaching of English as a foreign language to native speakers of 
Arabic, I have often felt frustrated by errors in my students' writing. I support the opinion that the first step an ESL/EFL teacher should take in order to deal with his/her students' performance errors is to identify these errors and then organize them in a systematic classification according to their type and source. Having done this classification of errors for each student, the teacher would then be able to provide special instructions and pedagogical work for each student according to his/her need (Hendrickson 1978). Therefore, this study examines some types of errors in the writing of Arab ESL students at college level for the purpose of enabling ESL teachers of this language group to recognize some of the frequent errors in their students' writing, to recognize the learning strategies the students employ and to provide some suggestions to help the students overcome these errors.

The types of errors this research focuses on are grammatical, lexical and stylistic. In selecting these error types, I have been guided by the findings of other error analyses that have focused on the performance of Arab learners of English and by my TEFL experience (Kambal 1980, willcott 1972, Scott and Tucker 1974). Sources of these errors are explained according to Richards' classification of errors as interlingual and intralingual (1971). 


\section{RESEARCH QUESTIONS}

Identifying errors in terms of their frequency, type and source is one-half of the communication event. The other half can be captured only by evaluating the communicative effect of errors from the perspective of the native speakers of the target language. The purpose of this study is, then, to examine which error type and source affect native speakers' understanding of the written passages.

The study will attempt to answer the following questions:

1) What kinds of inter- and intralingual errors are most frequently made by Arab students in the ESL upper intermediate and advanced levels? It is hypothesized that grammatical errors due to interference from Arabic are more frequent than intralingual ones; and that grammatical errors - both inter - and intralingual - are more frequent than semantic errors.

2) What is the ratio of intralingual to interlingual errors in the compositions under analysis? It is hypothesized that interlingual errors will be less frequent than intralingual errors in the students' writing at this advanced stage of ESL instruction, especially since the subjects in this study are learning English in its native environment, i.e., the U.S.A.

3) Which error type, grammatical or semantic, does the native speaker have difficulty understanding and/or 
accepting? It is hypothesized that semantic errors will be judged as more likely to affect communication than grammatical errors.

Richards (1971) classifies sources of errors into two types: interlingual and intralingual errors. Interlingual (transfer) errors result from the learner's attempt to make use of the system of his/her native language in acquiring the target language. Selinker (1972) uses the term "interlanguage errors" to refer to the structurally intermediate status of the learner's language system between his/her mother tongue and the target language. He describes inter-lingual errors as the type of learner's errors that are accounted for by interference from the mother tongue (1969). Interference errors are defined in the EA Iiterature as errors in the learner's use of the foreign language that can be traced back to the mother tongue. Dulay and Burt (1976) refer to interference as the automatic transfer, due to habit, of the surface structure of the first language onto the surface of the target language.

Richards (1971) describes intralingual errors as errors that "affect the learner's competence at a particular stage and illustrate some of the general characteristics of language acquisition" (205). He gives the following definition: "Intralingual errors are those which reflect the general characteristics of rule learning, such as faulty overgeneralization, incomplete application of rules, and failure to learn conditions under which rules apply" (206). Their cause and origins, claims Richards, are to be 
found "within the structure of English itself, and through reference to the strategy by which a second language is acquired and taught" (206). Such types of errors cannot be described as a mere lapse or failure of memory, but as indicative of transitional competence.

\section{SUMMARY}

For a framework of this study, Chapter II is a survey of some of the literature on contrastive analysis and error analysis and the implications of these two approaches to ESL error treatment in the methodology of teaching English as a second language. Literature on error gravity and a contrastive study of some features in the Arabic language and their counterparts in English are also included in this chapter. Research methodology, design, description of errors, description of subjects and data and statistical tools are explained in Chapter III.

Chapter IV of this study investigates certain types of errors and explains their possible sources as inter- or intralingual. Errors are also classified into three major categories according to their type: grammatical, lexical and semantic. Chapter $\mathrm{V}$ discusses the results of the communicative effect of selected types of grammatical and semantic errors on two different groups of native speakers of English and a group of native speakers of Arabic.

Chapter VI concludes this thesis with some in-class procedures and approaches to help alleviate the errors in the writing 
of Arab students at college level based on the findings of this study. 
CHAPTER II

\section{THE IMPORTANCE OF CONTRASTIVE ANALYSIS \\ AND ERROR ANALYSIS IN SECOND LANGUAGE LEARNING}

This chapter focuses on the literature of three major areas related to this study - Contrastive Analysis, Error Analysis and Error Gravity - and will conclude with a contrastive study of some major features in the Arabic language in the areas of writing style, word order and grammatical features and their counterparts in the English language.

\section{CONTRASTIVE ANALYSIS}

Over the past four decades applied linguists have become interested in studying the second language learner's errors in the hope that such studies would shed some light on the process of second language acquisition. The first attempt was made by proponents of Contrastive Analysis (CA), (Fries 1945, Lado 1957). The $C A$ hypothesis is based on the assumption that one of the major problems in second language learning is caused by interference from the native language with its structural differences. As a result of this view, it was suggested that a systematic comparison of the learner's native language (NL) and target language (TL) would produce a reliable basis for designing second language teaching materials and conducting classroom procedures (Lado 
1957). The goal of such comparison is to predict the errors that will occur in the learner's performance in the TL. The underlying assumption of $\mathrm{CA}$ is that the differences and similarities between the NL and the TL determine, respectively, the difficulty and ease with which the TL is acquired.

The contrastive analysis hypothesis is presented in two versions, the strong (apriori) and the weak (aposteriori). The apriori approach is based mainly on one-to-one description of the same level, for example, phonological levels of the native and the target language. The aposteriori approach calls for intensive comparison of the observed difficulties in second language learning.

The apriori version of $C A$ is best stated in the following quotation from Fries's Teaching and Learning English as a Foreign

\section{Language:}

The most efficient materials [for teaching a foreign language] are those that are based upon a scientific description of the language to be learned, carefully compared with a parallel description of the native language of the learner (1945:9).

The strong version of $C A$ requires linguists to contrast areas of phonology, syntax and semantics in both the NL and the TL. The pedagogical purpose of this comparison is to identify the areas of differences as possible sources of difficulty in learning a second language. The result of the comparison may help the teacher prepare and evaluate teaching materials and diagnose difficulties. It may also help him/her concentrate on the learning problems and on how they can be treated or avoided. Thus, 
differences between the two languages, in Lado's terms (1957), will result in "negative transfer" (i.e., interference from Ll). Positive transfer results from the existence of features that are common between NL and $\mathrm{TL}$, whereas negative transfer (interference) results from the existence of features that are different in the two languages.

However, the shortcomings of $C A$ detract from the comprehensiveness and generality of this approach to second language learning (Richards 1971). CA lacks the rules by which a linguist can analyze thoroughly and systematically the structures of two languages. This limitation of the strong version was clearly pointed out by Donald Wardhaugh (1970), who proposed the strong and the weak version of $\mathrm{CA}$. According to Wardhaugh, the strong version is the description of the structure of the language and the prediction of the areas of difficulty. However, this version, to him, is unrealistic and impractical because of the tremendous demands it makes on the linguist and on linguistic theory. The weak version, he explains, is that

- . which requires only from the linguist that he use the best linguistic knowledge available to him in order to account for observed difficulties in second language learning. It does not require what the strong version requires, the prediction of those difficulties and, conversely, of those learning points which do not create any difficulties (1970:126).

Therefore, whereas the function of the strong version is predictive, the aim of the weak version is explanatory.

According to John Carrol, transfers from Ll to L2 can occur at any level of an individual's response system. 
They [the transfers] can occur for example, at a "cognitive" level, where the learner's problem is one of selecting among alternative possible responses, or at a psychomotor level, where the problem is one of shaping the particular response topography. Transfer problems at the cognitive level would be exemplified by difficulties in selecting appropriate lexical items or syntactical structures, while those at the psychomotor level are illustrated by phenomena of "foreign accent" and inappropriate articulation of phonemes (1968:115).

When one is dealing with structural differences, the cognitive level of interference is of greatest concern. Psycholinguists claim that in learning the structure of a second language, Ll habits tend to inhibit or otherwise modify the learning of $L 2$. Their research, however, fails to define the degree of inhibition or facilitation that Ll might have on the process of learning L2.

In Linguistics Across Cultures (1957), Lado concludes that different structures impede learning, and they are difficult to learn. He gives clear examples of learning difficulties that are due to differences in the formal devices to convey the same meanings in the two languages. He presents the steps the analyst follows in carrying out his task. L2 is analyzed first and then compared with L1. The analyst needs to know if structure $A$ in L2 has an equivalent structure in $\mathrm{Ll}$ in terms of form, meaning and distribution (1957).

The procedure the linguist has to follow in the contrastive analysis hypothesis differs depending on the version to be followed. The strong version requires the availability of a comprehensive contrastive linguistic theory to guarantee the production of correct sets of contrasts between the two languages. The weak version uses apparent difficulties as a basis for con- 
trast. The proponents of the weak version attack the strong version on the grounds that the latter is impractical, time consuming, and often misleading (Schachter 1974). They support their claims by pointing out the differences between what a teacher might think is difficult and what is actually difficult for the students.

In general, one of the criticisms against $C A$ is that the results achieved through $C A$ were either of the type known to every experienced teacher, which could be revealed by means of error analysis, or were so abstract that their application to pedagogical purposes seemed to be fruitless. Another criticism against CA is that it limits the comparisons only to linguistic elements, which, according to proponents of the communicative approach, constitute only a part of the communicative competence of the learner. Lado (1957) asserts that preconceived notions that are formed by the foreign learner hamper his/her understanding of the foreign culture. Thus, it has become clear for researchers and teachers that not all errors that the L2 learner makes are due to negative transfer from his NL. Besides, not all errors are predicted by $C A$ and not all errors predicted by $C A$ occur in the learner's performance.

\section{ERROR ANALYSIS}

Recently, researchers have begun to view the learner's linguistic behavior as a creative process of constructing hypotheses about the target language. The learner in the error analysis 
hypothesis is no longer viewed as a passive recipient of instructions. Therefore, the interest of researchers and teacher has shifted from the CA treatment of errors to Error Analysis (Corder, 1957). EA is based on actual data that are collected from the learner's performance, and it does not restrict itself to one source of errors; i.e., interference or negative transfer.

Errors are an inevitable part of the process of language acquisition (Corder, 1967). They provide valuable feedback to both teachers and learners regarding learner strategies and progress. They also provide researchers with insights into the nature of the language acquisition process itself:

A learner's errors are significant in that they provide to the researchers evidence of how language is learned or acquired, what strategies or procedures the learner is employing in the discovery of the language (Corder, $1967: 167)$.

Under the influence of the recent views about the nature of language acquisition, second language learning is nowadays being approached as a problem of cognitive learning and the possession of a second language as a possession of L2 competence. According to Dulay and Burt (1974), the L2 learner possesses a set of cognitive structures acquired by some process of data-processing and hypothesis formation in which the making of errors is evidence of the learning process itself and probably not only inevitable but necessary. Thus, errors are not the result of a deficiency in the L2 learner's competence, but could be the result of other factors such as maturational development, motivation for learning and the circumstances of learning. 
ERROR GRAVITY

Over the past ten to fifteen years the aims of error analysis have changed. While initial studies focused on the frequency and types of recurrent errors committed by second language learners, a recent area of inquiry within error analysis concerns itself with the impressions and reactions of native speakers rather than the production of ESL learners per se, in an attempt to document the characteristics of successful and unsuccessful L2 communication (Savignon, 1983). The linguistic component of the message (pronunciation, grammar, and vocabulary) occupies a central place in these studies. In addition, several non-linguistic variables affect native speakers' reactions to the spoken or written work of L2 users. These variables include the personality of the speaker or writer, the use of communication strategies such as circumlocution, paraphrase, and appeal for assistance, the use of gestures, the continuity of the message (hesitations, false starts), and the possibility of cultural stereotypes or cultural clashes (Tomiyama: 1980).

Two criteria have been widely used in research on communicative error evaluation: intelligibility (comprehensibility) and acceptability. Obviously, the primary goal of language use is to communicate. Simply stated, the degree to which the interlocutor understands what is said or written is the measure of intelligibility. Estimates of intelligibility may be either subjective or objective, and each can be expressed quantitatively for analysis 
and comparison. Studies by Burt and Kiparsky (1972, 1974), Burt (1975), Guntermann (1978), Piazza (1979), and Tomiyama (1980) have employed intelligibility as a criterion for judgments of native speakers. Guntermann (1978), for example, found that semantic errors affected intelligibility more than did grammatical errors.

Closely related to intelligibility is acceptability, which is the degree to which a given L2 violates language norms. Judgments on acceptability may be influenced by factors other than personality, such as age, education, and the norms of the speech community as a whole. Native speakers' competence in their language enables them not only to interpret, but also to distinguish between acceptable and unacceptable communications. These distinctions, however, are not always as neat as researchers would like them to be. Both Chastain (1980) and Guntermann (1978) raised the issue of $\mathrm{ling}$ istic acceptability in psycho-social terms, pointing out that if the goal of the L2 learner is to establish social and personal relations with native speakers, certain errors may be more stigmatizing or more humorous than others. Incorrect or omitted adjective agreement in Arabic is a case in point: it does not usually interfere with intelligibility and is mildly irritating, but it does draw negative attention, particularly in personal interactions where the referent is obviously marked for gender, like a man using the feminine form of the adjective to describe himself.

Considerable work has been done on judgments of error gravity, making it possible to speculate with some certainty what 
specific kinds of $\mathrm{L} 2$ errors will provoke greater irritation than others. However, there is little in published research on the issue of personality or cultural variables that affect judgments of error gravity. For the individual respondent, these variables include age, sex, education, profession or social class, and degree of familiarity with foreigners. At the group level, some language communities may be more tolerant of errors than others.

\section{OBSERVATIONS ON SOME FEATURES IN THE ARABIC LANGUAGE \\ AND THEIR COUNTERPARTS IN ENGLISH}

It will be helpful for the purpose of this study to compare some features in the Arabic language and their equivalents in English. Since the analysis in this study is of compositions written by Arab students from different Arab countries, it is important to note that the different dialects that exist among these countries or even within the same country do not affect the results of this study. Scott and Tucker (1974) maintain that errors in writing result from interference from classical Arabic, while speech interferences come from the colloquials including the different dialects.

There are two distinct varieties in the Arabic language in every Arab country. The classical literary Arabic (Fushā) variety is used for purposes of written literature, education, religion, administration and the media. This variety is fully understood all over the Arab world, whereas the different colloquial (spoken) dialects are used in informal settings and are rarely used in reading or writing. 
Stylistic Patterns in Arabic and English

Kaplan (1976:12) maintains that Arabic has "the Iinguistic capacity for much more complex and elaborate forms of syntactic parallelism than English has." It may be noticed that Arabic has more syntactic markers for coordination than English. It also has fewer markers for subordination than English. This observation provides an explanation for the fact that stylistic parallelism is more prevalent in Arabic than in English. Stylistically, Arabic uses coordinated parallelism in preference to subordination (Kaplan, 1976).

Arabic uses long sentences. It relies heavily on preceding statements of the theme with repetition, paraphrasing, and explanation. English, on the other hand, uses explicit statements (clear and direct), with short sentences which are more to the point. It also relies heavily on the use of presequences, sentences whose main function is to signal that what follows is the theme. Explicit statements and presequences co-occur with the thesis statement and mark the theme explicitly (Kaplan, 1967).

Arabic writing style tends to over-emphasize a point by introducing information which the reader might consider obvious. Also, the Arabic style depends heavily on devices for assertion and exaggeration. The main points are over-asserted and overexaggerated. To achieve exaggeration, Arabic uses "special word endings, ways to double consonants, and rules for redundant pronouns like 'my professor, he is funny'" (Panos/Ruzik, 1983:611). 
To communicate ideas clearly, there is greater use of repetition, superlatives, frequent rewording and restatements.

Word Order in Arabic and English

Arabic and English are completely two different languages. With respect to structure, it may be safely said that Arabic and English are almost antipodal to each other. The morphology of Arabic is built on a system of tri-literal stems or roots. A word is fundamentally a sequence of three consonants. Different forms related to that word are derived by adding prefixes and affixes to the base. $K-T-B$ is such a base from which one may derive a lot of words (nouns, verbs, adjectives, adverbs):

$\begin{array}{lll}\text { /kitāb/ } & \text { book } & \text { singular noun } \\ \text { /kutub/ } & \text { books } & \text { plural noun } \\ \text { /maktabah/ } & \text { library } & \text { noun } \\ \text { /maktab/ } & \text { office/desk } & \text { noun } \\ \text { /kātib/ } & \text { writer/clerk } & \text { active participle } \\ \text { /maktüb/ } & \text { written } & \text { passive participle } \\ \text { /yaktubu/ } & \text { he writes } & \text { verb } \\ \text { /taktubu/ } & \text { she writes } & \text { verb } \\ \text { /kataba/ } & \text { he wrote } & \text { verb } \\ \text { /katabat/ } & \text { she wrote } & \text { verb }\end{array}$

English is different. Roots in English appear in syllabic form with at least one vowel. The variation and alternation of those vowels play a basic role in the structure of English. In Arabic, vowels are basically formative devices for derivational 
purposes and function.

With respect to word order, Arabic is different from English. In statements as well as questions the verb precedes the noun or subject.

$\begin{array}{lll}\text { Examples: } & \text { Went the boy to school. } & \text { statement (Arabic) } \\ & \text { The boy went to school. } & \text { statement (English) } \\ & \text { Did went the boy to school? question (Arabic) } \\ & \text { Did the boy go to school? } & \text { question (English) }\end{array}$

Questions in Arabic are formed by the addition of question words at the beginning of a statement (/hal/, / limāeā/, /ayna/), etc. This observation may explain the difficulty Arab students have in subject-verb inversion in questions in English.

In English, the adjective precedes the noun as in "the big book." In Arabic, the adjective follows the noun as in "the book the big." Compound nouns like "White House," "greenhouse" and "area code" are not as commonly used in Arabic as they are in English. Instead, this structure in Arabic is a noun-adjective combination.

Grammar in Arabic and English

In reference to grammar, English has fewer morphological endings than Arabic. The genderless and caseless noun and verb conjugations are examples. But other differences which might be considered more difficult by Arabic-speaking students might be the cause of some interference. The use of the definite pronoun in Arabic and English will be discussed first. In Arabic, mass nouns, whether used in the concrete or abstract sense, take the 
article prefix. Examples:

$\begin{array}{ll}\text { Increase of the production... } & \text { (Arabic) } \\ \text { The milk is nutritious. } & \text { (Arabic) }\end{array}$

But in English these nouns take the definite article only when they are specified. In this case, the above examples would be written in English as follows:

\section{Increase of production... \\ Milk is nutritious.}

Also, in Arabic, abstract nouns take the definite article following the Modern Classical Arabic pattern. Examples:

The philosophy is an important science. (Arabic)

Philosophy is an important science. (English)

Another area where the use of the definite article is different is gerunds. In Arabic, gerunds require the definite article. The following examples illustrate this point:

The speaking well....

Speaking well....
(Arabic)

(English)

Plural countable nouns used in the generic sense do not take the article in English, but they do so in Arabic. Examples:

The books are useful. (Arabic)

The children are innocent. (Arabic)

Another category of difference is verbs. The most important 
difference is the technical absence of the form of the auxiliary or copula in Arabic. Examples:
He absent.
(Arabic)
He is absent.
(English)
My teacher angry.
(Arabic)
My teacher is angry.
(English)

The above examples, although ungrammatical in English, would be well-formed in Arabic. They are examples of equational sentences, which correspond to English sentences with "be" in the present tense affirmative. The major difference is that there is no verb present in an Arabic sentence of this type. Yet the meaning of the omitted auxiliary verb is implied and the Arabic native speaker is aware of it.

As for rules governing the use of verbs in Arabic sentences, they are quite distinct from those in English. First, Arabic is a highly speculative language. While English can combine a number of tenses with simple, perfective, and progressive aspects, Arabic makes two basic distinctions, the perfect and imperfect aspects. The perfect is used to describe a completed action (frequently in the past), while the imperfect describes a situation not yet completed (often in the present or the future). But since these aspects derive their meaning from the point of completion or incompletion of the activity rather than the time of completion or incompletion, both aspects may be used to describe an action in the past, present, and future. Examples: 
After I finished my work, I went to the theater. (Arabic) After I had finished my work, I went to the theater. (English) Before I go to bed, I drank my milk. (Arabic) Before I went to bed, I had drunk my milk. (English)

In Arabic the meaning and time reference of the verb in a subordinate clause is derived from the time of the verb in the main clause (Panos 1983:611). Therefore, an imperfect verb in a subordinate clause following a perfect verb in the main clause refers to the same time as the verb in the main clause. The following sentence translated directly from Arabic shows how the imperfect tense in a subordinate clause refers to the same time as the verb in the main clause:

The minister arrived (perfect) while he carries (imperfect) an important letter from the president. (Arabic)

Here, the imperfect tense denotes an action taking place at the same time as the main verb. The same idea can be expressed in English as follows:

The minister arrived carrying an important message from the president.

Here is another example for the use of the perfect tense with the particle in a subordinate clause:

The reporter returned (perfect) to his country while he (particle) talked (perfect) with the president. (Arabic)

Here the use of the perfect tense indicates a completed action and 
the particle clarifies the sequence of events. In English one could say:

The reporter returned to his country after having talked with the president.

Another main difference in grammar between Arabic and English is the relative clause. The first major difference is the relative pronoun in Arabic. A relative particle, which is part of neither clause, links two complete clauses (Panos 1983:613). This particle is present only when the antecedent is definite, as in the following sentence:

I saw the boy who he had red hair. (Arabic)

This sentence translated literally from Arabic has the pronoun "he" which is not present in the English counterpart. When the antecedent is indefinite, no relative pronoun occurs, as in:

I saw a boy, he has red hair. (Arabic)

Another important difference is that the antecedent clause and relative clause in Arabic are both complete sentences; neither is subordinate. From the previous discussion, it becomes clear that the relative clause construction in Arabic is coordinate rather than subordinate as in English.

Studies on Arab Learners of English

A number of studies have investigated the performance of Arab learners of English. Willcott (1972) classified errors according to syntactic categories. He found that errors in 
definiteness were the most widespread. Scott and Tucker (1974) described the "transitional grammar" of 22 Arab college students and rank-ordered the areas of difficulty. They found that verbs, prepositions and articles were the most problematic area for Arab learners of English. Kambal (1980) analyzed syntactic errors made by Sudanese learners of English. He found that errors in verbs, tenses, concord, articles, and prepositions constituted the highest percentage of errors in all the compositions that he studied. Mukattash (1981) investigated Wh-question errors made by freshmen Jordanian learners of English. He found that some of the errors in Wh-question formation were due to interference from Arabic, while other errors were similar to those made by a child learning English as his/her first language. He classified the latter set of errors as intralingual. Kharma (1981) analyzed errors in the use of articles. His findings have demonstrated that the easiest article for Arab students to learn was "the" followed in the rate of difficulty by "a/an", and finally by "no article."

This chapter focused on some of the literature on contrastive analysis, error analysis and error gravity. An attempt was also made to contrast stylistic patterns, word order and some grammatical features in the Arabic language and their counterparts in the English language. 
CHAPTER III

METHOD

In this chapter, description of subjects and data along with method and design, types and sources of errors, and statistical tools are discussed.

\section{SUBJECTS}

The subjects of this study were 30 Arabic-speaking students in the upper intermediate and advanced levels in English as a second Language programs at four colleges and universities in oregon. The compositions under analysis were written by these students as a practice Test of Written English (TWE) examination or in writing tests given as part of a placement exam at these colleges in different quarters of the year 1987. Only the compositions of those students who were placed in the upper intermediate and advanced levels were included in this study. The thirty compositions under analysis were selected randomly from the 56 written by Arab students from the following Arabic-speaking countries: Saudi Arabia, Yemen, United Arab Emirates, Kuwait, Qatar, Bahrain, Jordan, Lebanon, Iraq, Syria and Oman. Although educational systems vary, when students from any of these countries finish high school they have had an average of eight years of English instruction. Their average age is about 19 years old, 
both males and females. All are native speakers of Arabic.

RESEARCH DESIGN

Errors in the compositions under analysis for this study have been identified and classified under three categories: grammatical, lexical and stylistic. Explanations of the sources of these errors are in terms of inter-and intralingual.

Interlingual (transfer) errors result from the learner's attempt to make use of the system of the NL in acquiring the TL. Richards (1971:205) gives the following definition of intralingual errors: "Intralingual errors are those which reflect the general characteristics of rule learning, such as faulty overgeneralization, incomplete application of rules, the failure to learn conditions under which rules apply." Richards'definitions and classifications of inter- and intralingual errors were adopted as a framework for this thesis because these definitions and classifications are adequate and account for the types of errors that were found in the compositions under analysis in this study.

Grammatical errors, both inter- and intralingual, include those errors that occur at the sentence level. This study does not include all types of errors in sentence structure; it concentrates on the following areas: sequence of tenses (maintaining the sequence of time reference(s) within the same sentence), subject-verb agreement (the English rule states that a subject must agree with its verb in number), omission of the copula (verb "to be" or any of its forms), substitution of prepositions, and 
omission and substitution of articles, both definite and indefinite. Lexical errors are mainly lexical substitution. Stylistic errors reflect some features of Arabic writing style such as redundancy and run-on sentences. In selecting and categorizing these error types, I have been guided by other error analyses that have focused on the performance of Arab learners of English, by my TEFL experience, and by the judgment of an Arabicspeaking expert who has been working in the field of error analysis for over thirty years. Thus, the design for the error analysis is organized as the following:

I. Interlingual Errors:
a. Articles
b. Prepositions
c. Copula
d. Embedded questions
e. Pronoun Retention
f. Semantic errors: lexical substitution and word-for-word translations of idioms

g. Stylistic errors

II. Intralingual errors:

a. Overgeneralization: embedded questions and concord

b. Ignorance of Rule Restrictions/Incomplete Application of Rules: sequence-of-tenses rule, subject-verb agreement. (Appendix $B$ includes examples of errors due to native language transfer, errors due to overgeneralization, and errors due to ignorance of rule restrictions.) 
A questionnaire was designed in order to determine the communicative effect of selected types of errors on three different groups of judges. It contained twenty grammatical errors in these areas:

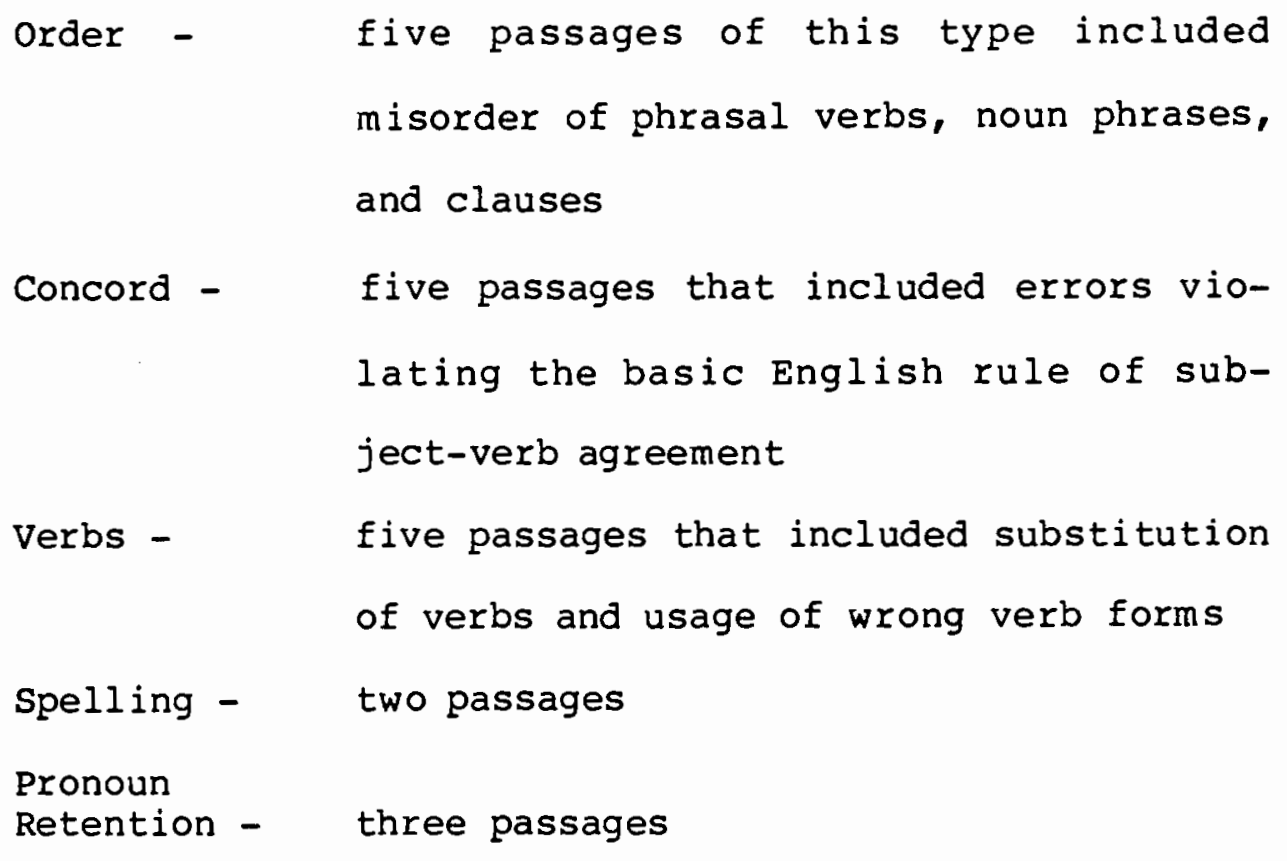

It also contained ten semantically deviant errors in the following areas:

$$
\begin{aligned}
\text { Wrong Lexis - } & \text { five passages that used wrong vocabulary } \\
& \text { items } \\
\text { Collocation - } & \text { five passages that used word-for-word } \\
& \text { translations from Arabic, especially } \\
& \text { translations of idiomatic expressions }
\end{aligned}
$$

The questionnaire contained thirty erroneous passages. The passages were edited and revised so that each one contained only one grammatical or semantic error in the areas specified above. Two measures were employed to check the communicative effect of the selected erroneous passages. They were intelligibility (the 
readers' understanding of the meaning of the passage) and acceptabilty (the degree to which the interlocutor thought each passage violated the English language norms). A 4-point scale was used for each of the measures, with number 1 being less intelligible or acceptable and number 4 being highly intelligible or acceptable. (A copy of the questionnaire is found in Appendix C.) The questionnaire was pilot-tested on a group of eight people. It included a third measure, naturalness. This measure was dropped from the questionnaire because the results of judgments on the naturalness measure were not as significant as those on the intelligibility and acceptability measures.

The judges, those who responded to the questionnaire, consisted of three different groups, 15 in each group. One group consisted of 15 students enrolled in a course called "Methods of Teaching ESL"; the majority are native speakers of English and all are studying for either an M.A. degree in TESOL or a certificate in TESL; i.e., they will become ESL teachers in the future. The second group consisted of 15 American undergraduates enrolled in a college freshman writing course during the winter Term of 1988 . They are considered peers to the Arab students who wrote the compositions under analysis. The third group consisted of 15 Arab students enrolled at a university in oregon where the instruction and curricula are in English. The last two groups both included students from a wide range of academic fields. 
CHAPTER IV

INTERLINGUAL AND INTRALINGUAL ERRORS IN

ARAB ESL STUDENTS' ENGLISH COMPOSITIONS

\section{INTERLINGUAL ERRORS}

Interlingual errors are transfer errors. They result from the learner's attempt to make use of the system of his NL in acquiring the TL. Selinker (1972) uses the term "interlanguage" errors to refer to the structurally intermediate status of the learner's language system between his/her mother tongue and the target language. He describes interlingual errors as the type of learner's errors that are accounted for by interference from the mother tongue (1969). These transfer errors are seen to be structurally simpler in comparison to the fully complex TL. Errors in this classification follow a certain pattern of perception and production by the learners of the TL, especially if the learners have the same NL.

In this study seven types of errors have been identified under the interlingual category: articles, prepositions, the copula, embedded questions, pronoun retention, semantic and stylistic errors. (Appendix B provides a sample of these errors).

Table I on the following page presents the relationship between types and sources of errors. The different types of grammatical and semantic errors are presented in columns. The 
numbers inside the squares show the distribution of errors according to their source, inter- or intralingual. The ratio of interlingual to intralingual errors is $2.4: 1$. The three rows in the table represent the distribution of sources of errors as interlingual (interference) and intralingual (overgeneralization and ignorance of rule restrictions). The ratio of grammatical errors, both inter- and intralingual, to semantic errors, also inter- and intralingual, is 7:1. The number of stylistic errors is not included in this table because of the difficulty of making a frequency count of stylistic errors at the paragraph level and essay level. The whole composition could have been written following the Arabic style of paragraph structure.

TABLE I

THE RELATIONSHIP BETWEEN TYPES AND SOURCES OF ERRORS

\begin{tabular}{|c|c|c|c|c|c|c|c|c|c|c|c|}
\hline & \multirow{3}{*}{ SOURCES } & \multicolumn{9}{|c|}{ CATEGORIES } & \\
\hline & & \multicolumn{7}{|c|}{ GRAMMATICAL } & \multicolumn{2}{|c|}{ SEMANTIC } & \\
\hline & & 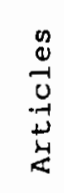 & 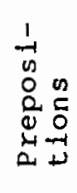 & 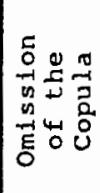 & 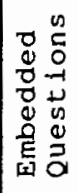 & 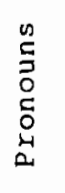 & 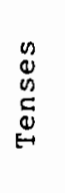 & 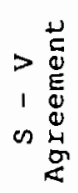 & 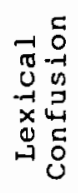 & 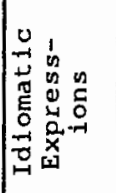 & $\begin{array}{c}0 \\
\substack{\pi \\
+\\
0} \\
i=1\end{array}$ \\
\hline 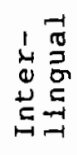 & Interference & 59 & 51 & 30 & 12 & 8 & 5 & 0 & 17 & 12 & 194 \\
\hline \multirow{3}{*}{ 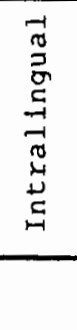 } & $\begin{array}{l}\text { Overgeneral- } \\
\text { ization }\end{array}$ & 3 & 2 & 0 & 5 & 0 & 11 & 29 & 0 & 0 & 50 \\
\hline & $\begin{array}{l}\text { Ignorance } \\
\text { of Rule } \\
\text { Restrictions }\end{array}$ & 0 & 6 & 0 & 1 & 0 & 8 & 10 & 6 & 0 & 31 \\
\hline & Totals & 62 & 59 & 30 & 18 & 8 & 24 & 39 & 23 & 12 & \\
\hline
\end{tabular}

The Ratio of Grammatical Errors to Semantic Errors - 7:1 The Ratio of Interlingual to Intralingual Errors - 2.4:1 
1. Articles:

Articles were the major problematic area for Arab students in the papers under investigation. Table I shows that 62 errors were made in the use of articles, 59 of which could be explained by interference from Arabic. Arabic has a definite article /al/, but indefiniteness is indicated by the suffixal ending of the noun. This addition of a suffix is referred to as "nunation". For the word/kitab/ "book", Arabic has the following endings:

Indefinite Nominative: / un/, e.g., kitābun vs. Definite: /al-kitābu/ Indefinite Genetive/Dative: / $\mathrm{in} /$, e.g., kitābin vs. Definite /al-kitābi/ Indefinite Accusative: / -an/, e.g., kitāban vs. Definite /al-kitäba/

In colloguial Arabic, indefiniteness is expressed by the noun without any article. Thus, omission of the indefinite article is attributable to Arabic interference. The following passages occurred in the data under analysis. All the examples used for illustration were drawn from the compositions under analysis.

1) *It's very old man.

2) *It was very interesting one.

3) *...to behave in good way.

4) *... very good aim.

5) *...correct and effective way. 
There were very few instances of the omission of the definite article (e.g., * to use library). The definite article was redundantly used in constructions with nouns that required the definite article in Arabic, but not in English.

The underlined nouns in the following erroneous passages are always definite in Arabic especially when used in a generic sense or with abstract terms:

6) *It meant for him the death.

7) *...the value of the time.

8) *...the higher education.

9) *... in the high school.

10) *....one builds the friendship.

11) *work give us a real taste for the life.

12) *The work is not every thing.

Note: Ungrammatical passages are marked by an asterisk (*).

2. Prepositions:

English prepositions constitute a major difficulty for Arab students, who have the tendency to substitute the Arabic equivalent for the appropriate English preposition. Table I shows that 59 errors in the use of prepositions were found in the compositions under analysis, 51 of which could be explained by interference from Arabic. Usually, preposition usages are languagespecific and they do not translate or match up well between related languages. In the following passage the preposition with is unnecessarily used with the verb treat. 
13) *I have learned much about treating with others.

The Arabic equivalent for treat is usually accompanied by the equivalent of the English preposition with. Another example of the inappropriate use of Arabic equivalents for English prepositions is the following:

14) * Judge on things.

The Arabic equivalent for judge is al ways followed by the equivalent of on. The learner is extending a correct usage in Arabic to the English context. He is translating the Arabic preposition into English. Other examples of Arabic interference are *in the third day, *think in.

\section{The Copula:}

Scott and Tucker (1974) maintain that the omission of the copula and the auxiliary by Arabic speakers is attributed to Ll interference. The assumption is based on the fact that Arabic technically has no auxiliary or copula. This fact explains the frequent occurrence of the common error of dropping the copula and its other forms. Table I shows that 30 errors made in the use of the copula in the compositions under analysis could be attributed to interference from Arabic. The following ungrammatical passages exemplify such an error:

15) *That what I hope to have.

16) *When there somebody with me.

17) *Wen you 5 years old. 
18) *Also in the United States all peoples good and friendly. 4. Embedded Questions

The following ungrammatical passage is attributable to interference from Arabic:

19) *They did not plan how could they get out of this. This is an instance of inversion in embedded questions. Subjectverb inversion is retained. In Arabic, a wh-word is usually followed by a verb and a subject. The order is wh-v-subject. This structure has been transferred to English, but other factors may contribute to the explanation of this error. The learner has learned a rule about subject-verb inversion in direct questions. He has overgeneralized this inversion rule to indirect questions. The teaching method of overemphasis on elicitation through direct questions may have facilitated or induced the occurrence of such errors. The fact that this single error has been traced to three sources, i.e., transfer, overgeneralization, and teaching situation, shows how difficult it is to ascribe errors unambiguously to one source. According to Table I, eighteen errors were made in the use of embedded questions, 12 of which could be attributed to interference from Arabic. Other examples of the same sort are:

20) *Finally, the visitor may be interested in seeing and knowing how is Saudi Arabia trying to be a developed country.

21) *People misunderstood what did it mean to be civilized.

\section{Pronoun Retention:}

A retained pronoun is considered a reflection of a relati- 
vized noun in a relative clause. The original embedded sentence loses its subject NP or object NP and gets a relative pronoun (who, which, whom, that) instead. Eight errors were found in the use of pronouns as shown in Table I; all were due to interference from Arabic.

The following error exemplifies a case of language transfer by Arab students:

22) *These things which I make them before the exams.

This is an example of the retention of a pronominal reflex of the relativized noun in relative clauses. The following error is an example of the retention of pronominal subject:

23) *...five subjects which they are.

24) * The sports players who they love to play and training.

The redundancy of subject and object pronouns is attributable to interference from Arabic, in which a pronominal reflex occurs in subject and object NP positions. On this basis one can explain why errors in pronominalization are likely to occur in the performance of Arab students. This aspect has also been discussed by Schachter (1974).

Among the eight examples of pronoun retention that were detected in this study, five were cases of subject retention, while the other three were examples of retained pronouns in the objective case. However, one of the important findings in Scott and Tucker's study (1974) was that the object-deletion rule is 
acquired later than the rule for subject deletion.

\section{Semantic Errors:}

Similar lexical items in one language may express different meanings in another language. Semantic restrictions on the use of lexical items may differ from one language to the other. Thus, errors in word use are related to semantic and distributional differences in use rather than to structural dissimilarities between the NL and the TL. The Arab student's misuse of pairs of lexical items such as learn and teach results in the production of erroneous passages. Table I shows that 17 of the 23 errors in the use of lexis found in the compositions under anlaysis were due to interference from Arabic. The following passages were produced by Arab students:

25) *They learned the pupils how...

26) * My lesson learn me...

27) *How can my parents learn me to use computers while they don't know anything about them?

This confusion can be explained in terms of semantic interference from Arabic in which the equivalents for the verbs teach and learn derive from one root, i.e., f-l-m. The two constructions "He taught me" and "I learned from him" have the following equivalents in Arabic:

He taught me

$$
\begin{aligned}
& \text { fallam-a-ni } \\
& \text { taught-he-me }
\end{aligned}
$$




$$
\begin{aligned}
& \text { I learned from him } \\
& \text { ta- fallam-tu-min-hu } \\
& \text { past-learned-I from him }
\end{aligned}
$$

The Arab student has transposed both English verbs (learn and teach) into learn on the basis of analogy from Arabic.

The following passage is an example of a violation of collocational restriction that is operative in English but not in Arabic:

28) *I began to walk on the rules.

The student is confusing an English idiom "to follow the rules" with the Arabic idiom "to walk on the rules." In English walk does not collocate with rules, whereas the Arabic equivalent does. The student has transferred a possible Arabic juxtaposition of words into English. He/she has had a recourse to word-for-word translation, which is a common strategy among Arab learners of English. The following passage is another example of this strategy :

29) *Books which have relations with my lessons.

The equivalent Arabic construction is acceptable, but its overextension to English is not. This is another instance of a violation of a collocational restriction that is due to interference from Arabic. Other examples of overextension of Arabic idiomatic expressions into English are the following: 
30) *The teacher came to the class and his condition's tongue says that he will give us a quiz.

31) *They ate him fleshly and threw him boney.

When one examines the above two examples closely, one notices that they show very serious semantic errors that could totally impede communication with the native speaker of English. In sentence number (30) the student translated an Arabic idiomatic construction into English without considering the semantic restrictions in English on such collocational phrases. According to Table I, twelve errors were found in the use of idiomatic expressions; all were considered interlingual. The underlined words in sentence number (30) mean "the teacher's facial and non-verbal expressions conveyed the message that he was going to give his students a quiz." The meaning of the passage in example (31) is similar to the English saying: "They were fair-weather friends." This English saying does not convey the same meaning it conveys in its English form when translated word-for-word into Arabic. The above two examples are acceptable in Arabic; in fact they show eloquence when used in a proper context. But the student's wordfor-word translation strategy of these two constructions is unacceptable in English and results in ambiguous passages.

The following passage is another example of the student's attempt to convey a message in English using an Arabic expression:

32) *The biggest university in Oman is called Sultan Qaboos University. It has a dangerous and great letter.

In this passage the word message has been replaced by letter. 
Both words, message and letter, have one root in Arabic. Moreover, the word dangerous does not collocate with letter in the English context, bearing in mind the writer's intended meaning of message. But in Arabic the equivalent of dangerous may be used to modify the word letter with the intended meaning of important.

Another example of a lexical confusion that is due to interference is the lexical pair doctor and professor. Arabic has borrowed the English word doctor. It refers to both medical doctors and professors. The Arabic student transfers this equivalency into English and produces the following unacceptable passage:

33) ?The doctors gave us low grades.

Note: Unacceptable passages are marked by a question mark (?).

The word doctors has been substituted for professors. The following passage is an example of ignorance of rule restrictions (Richards, 1971):

34) *Alia became old and nobody asked her for wedding.

The words wedding and marriage have the same root in Arabic. Therefore, the Arab learner used wedding instead of marriage. According to Richards (1971), this error is due to interference and ignorance of rule restrictions and exceptions in using lexical items because wedding is a part of marriage and it cannot replace marriage in a sentence as its lexical item, just as dialects are a form of a language and as roses are a kind of flower. Wedding is 
not in an exclusive relationship with marriage, but rather in an inclusive one. This kind of error shows that the learner has not learned one part of the lexico-semantic system of English. The errors in sentences (32) and (34) could also be due to the use of bilingual dictionaries where the student can find different synonyms for one word. They may also reflect the absence of context when they were introduced to the students; i.e., the students might have been taught these words and their meanings in Arabic in the form of bilingual lists with reference to one context or without a context.

In the following passages interference from Arabic is the source of the errors that the student made:

35) *...believing in this way as an only guidance to learn the facts of life is wrong, because life events and accidents are not the same throughout the history.

36) * There are many events and accidents occur in the life.

37) *Many people were killed in the event between the two cars.

The English terms event and accident share one root in Arabic, /hädie/. The student is using this term to mean both event and accident. In sentence (37) the student replaced the term accident by the word event, depending on his borrowing from the NL. In sentences (35) and (36) the student might not have been sure which term to use so he wrote both words. An accident is not in an exclusive relationship with an event, but it is in an inclusive one. The word accident does not always reflect a negative thing or attitude because we can say that "we have met some of our 
best friends by accident." The word event could also be used to describe both good and bad things, e.g., accidents, tragedies, occurrences, birthdays, football games, a new president's election or speech, etc.

The English quantifiers much, many, a lot and too much are semantically covered by one lexical term in Arabic, i.e., /Kaeīr/. It is used with nouns without any distinction whether the noun is count or uncount, common or mass. Furthermore, almost always it occurs after the noun. The following passage is due to interference from Arabic:

38) *I've learned too much at this University.

This passage is erroneous since it is followed by a listing of the good things that the student has learned. Therefore, the meaning of too much is a lot or very much in this passage.

\section{Stylistic Errors:}

Stylistic interference is another aspect of the influence of the NL on the learning of the TL. Ferguson (1959) introduced the term "diglossian" to describe situations where a single language has two (or more?) varieties, high and low, that are used for different functions. In the case of Arabic, the classical (high) variety is used for purposes of written literature, education, religion, administration and the media, whereas the different colloguial (low) dialects are used in daily life matters. Arab learners enjoy having at their command the language of the Qur'an: the formal classical variety. This variety provides them with the 
essential tools of effective rhetoric. They master the manipulation of high-sounding expressions. Transfer of such stylistic features into English often results in the production of ungrammatical and unacceptable passages. The following passages illustrate this point:

39) *He wants to pleasure him.

40) *I prefer my father enjoyment because of its achievement in contrast of his friend's enjoyment achievement.

41) *I could width my knowledge.

42) *I hope to gain more in the becoming semester.

43) *Too many exams caused us to improve a lot.

44) *Every minute worths a lot.

45) *I was delighted by some of them and disgustful for others.

46) *To drink knowledge and experience from them.

The last phrase is a word-for-word translation of an expression that is acceptable in Arabic. The learner's search for pompous words and expressions traps him/her into making different types of errors.

Arabic style tolerates prolixity and redundancy. The use of long-winded passages and the clustering of redundant adjectives are among the common features that the Arab student carries over to the learning of English. Short sentences are usually strung together with and, so, because and other conjunctions. This stylistic feature of the Arabic language is called coordination as opposed to subordination, a major style in the English language. 
This is the reason why it was difficult to include a frequency count of stylistic errors in Table $I$.

Koch (1983a) refers to coordination between two or more lexis in the Arabic language as "lexical couplets", and she refers to the repetition of thoughts in the Arabic style as "presentation" of the ideas through repetition and assertion for the purpose of persuasion (1983b). When Arab students transfer these stylistic features of their NL, they often produce run-on sentences. The following unacceptable passages exemplify errors that show redundancy:

47) ?...useful and beneficial learning.

48) ?...behave well and be polite.

49) ?...how time is important in the life of the person, and in the life of every individual in the society.

50) ?... the most beneficial and important things.

51) ?The new educational system has many useful benefits.

52) ?... important to everybody and useful to everyone.

The Arab learner's strategy might be to impress the reader through use of prolix expressions. This strategy can be detected in most of the writings of Arab students in this study.

The preceding discussion points to a tendency among Arab students to use eye-catching expressions for purposes of what they think to be effective style. This leads them into a maze of contextually unacceptable passages. What works in Arabic may not work in English. It is in these introductory passages that common errors of redundancy and run-ons occur. The following passages 
exemplify this point:

53) ?For my own advantage, and for myself, I learn many new things about our life and living.

54) ?The most benefit and important things which I learned them outside and inside class during this semester are the following:...

55) ?My parents advice supplies me with so many benefits, because I find there is something I don't know it yet and my parents help me to know it, and I be with my friends better than in the past.

56) ?Everybody in the universe tries to have a better life, tries to make himself or herself as happy as the best one, so most of the people try to know the best way of having a good life.

57) ? I think if I have too much monye my problems will be more and more and I will start to know that I can have everything I want so I will be Kearless and from this point I am going to be lease and heat my work because I will feel that I am not working, I am doing nothing because my monye works not me, I am not tired anymore with my work and this is terible, yes because if you think that everything wil ease and you did not work hard on it the life will be so boring.

58) ? There are many main factors play a good role in the University as a small society in building the students physically and educationally inside and outside its gate.

\section{INTRALINGUAL ERRORS}

Many linguists (Richards, Selinker, Corder, Nemser) agree that interference from the learner's mother tongue does not account for all the errors that the L2 learner makes. These Iinguists, and others, noticed that some of the errors the L2 learner makes are similar to the errors made by a child trying to learn his/her first language. Research in psycholinguistics on errors made by children trying to learn their mother tongue proved that 
these errors follow certain patterns and are evidence of developmental stages in the child's language acquisition process. Because of the fact that these errors are similar between the two learning groups, they are not considered to be attributable to features of the mother tongue of the L2 learner. They could result from the learning process itself. Learners are seen to make inductive generalizations about the target language system on the basis of the data to which they are exposed. Since the data are necessarily restricted, learners tend to overgeneralize and produce incorrect forms by analogy. This process results in the reduction of the target language system to an apparently 'simpler' form (Richards, 1974). Richards (1971:206) gives the following definition of intralingual errors: "Intralingual errors are those which reflect the general characteristics of rule learning, such as faulty overgeneralization, incomplete application of rules, and failure to learn conditions under which rules apply."

\section{Overgeneralization:}

Selinker (1972) refers to the process of overgeneralization as an "extension" of a rule in the TL to an "environment" in which it does not apply. Jakobovits defines generalization or transfer as:

The use of previously available strategies in new situations... In second-language learning...some of these strategies will prove helpful in organizing the facts about the second language, but others, perhaps due to superficial similarities, will be misleading and inapplicable (1969:62).

Thus, overgeneralization covers instances where the learner 
creates a deviant structure on the basis of his experience of other structures in the target language. Table I shows that 50 overgeneralization errors were found in the data under analysis. In addition to those discussed below, examples of errors due to overgeneralization are provided in Appendix B.

There exists in English a restricted generalization about subject-verb inversion in direct questions. The Arab learner overgeneralizes this inversion rule to English embedded questions. The following ungrammatical passages are attributable to overgeneralization:

59) *I don't know when does the holiday start.

60) *We could not believe what did he say.

61) *I asked him what was his name.

One might explain this phenomenon in terms of "ignorance of rule restrictions." Subject-verb inversion applies only to direct questions. Embedded questions behave like ordinary statements with regard to inversion. Another reason for this type of error could be traced to inadequate or faulty teaching techniques or materials. This again points to the indeterminate nature of the explanation of sources of errors in terms of well-defined categories of sources. More than one source can be detected. However, in Table I, 29 errors in subject-verb agreement were found to be due to overgeneralization.

Second language learners, like children, look for regularities; sometimes they make up their own regularities in the lan- 
guage to which they are exposed. For example, they overgeneralize the ed suffix for past tense formation. They sometimes overgeneralize this rule to inappropriate contexts. The following passages were produced by one of the subjects of this study:

62) *I feeled that I have many responsibilities.

63) *...according to the things he teached me.

The following shows lack of concord between subjects and verbs :

64) *He provide him with...

65) * He get bored...

66) *he use it to shoot...

The third person $\underline{s}$ has been omitted. The student overapplied a restricted generalization in English to third person forms. The strategy employed here by the student could be to reduce his linguistic burden. With the omission of the third person $\underline{s}$, overgeneralization removes the necessity for concord, thus relieving the learner of considerable effort trying to remember the exception to the rule. This phenomenon, the omission of third person $\underline{s}$, has been investigated by Duskova:

Since [in English] all grammatical persons take the same zero verbal ending except the third person singular in the present tense...omissions of the $s$ in the third person singular may be accounted for by the heavy pressure of all other endingless forms. The endingless form is generalized for all persons, just as the form was is generalized for all persons and both numbers in the past tense...Errors in the opposite direction may be explained either as being due to hypercorrection... or as being due to generalization of the $3 \mathrm{rd}$ person singular ending for the $3 \mathrm{rd}$ person plural (1969:36). 
In fact, there was one error in the compositions under analysis that occurred in the opposite direction of the general rule of the third person singular $\underline{s}$ :

67) *Tourists enjoys the beautiful sandy beaches of the Eastern province in Saudi Arabia where they can swim in the gulf.

As mentioned above, this error in concord can be due to generalization of third person singular ending or hypercorrection.

2. Ignorance of Rule Restrictions (exceptions)/Incomplete Application of Rules

Richards (1971) gives the following definition of the concept of ignorance of rule restrictions: "Closely related to the generalization of deviant structures is failure to observe the restrictions of existing structures, that is, the application of rules to contexts where they do not apply" (208). When he talks about incomplete application of rules he says: "Under this category we may note the occurrence of structures whose deviancy represents the degree of development of the rules required to produce acceptable utterances" (209). Table I shows that 31 errors due to ignorance of rule restrictions were found in the compositions under analysis. Additional examples of errors that are traceable to ignorance of rule restrictions from the compositions under analysis are provided in Appendix $B$.

In English, there are some restrictions on the tenses of verbs when more than one occurs in an utterance. This rule is referred to as the sequence-of-tenses rule. Mixing of tenses results in the occurrence of errors. Table I shows that eight 
errors in the use of tenses were found to be due to ignorance of rule restriction. For instance, the following sentences are ungramnatical:

68) *He was reading a story when I arrive.

69) * Some people know that and tried to correct for the others.

70) *It was marvellous yet people misunderstand what did it mean to be civilized.

However, the following sentence is grammatical:

Galileo said that the earth is round.

The embedded clause in the above sentence expresses a general scientific phenomenon, i.e., the roundness of the earth. The Arab learner of English might have failed to observe the restrictions that are imposed on the sequence of tenses. The following are additional examples of such errors:

71) *The women dislike the men and wanted to get rid of them.

72) *If we missed a class, we will not understand the next one.

73) *At school I used to study from the books we receive.

74) *In class I always do what my teacher told me.

2) The English rule of subject-verb agreement is another problematic area that is traceable to ignorance of rule restrictions. In English, third-person singular subjects are followed by a verbal root plus $-(e) s$. This restriction applies only to the present tense. In Arabic, verbs agree with subjects in person, 
number and gender, so there should be a positive transfer.

The following passages show how the Arab student fails to observe the above restriction. In some cases, a singular subject is followed by a plural verb; in others a plural subject is followed by a singular verb.

75) * That make me happy.

76) *When there is students in it,...

77) * The two man who plays the game...

78) *There are people who thinks that activity is more
important than work.

Errors in subject-verb agreement occur with both singular and plural subjects. That is, about half of the errors involve cases of plural subject and singular verb, while the other half involve cases of singular subject and plural verb. One might be tempted to interpret the latter cases as instances of simplification. This simplification strategy is thought to be employed by all language learners. The learner has learned the rule of subject-verb agreement, but he/she is indiscriminate about the contexts in which it applies. Some students fail to apply it. others apply it in the wrong context.

The failure to use the $\underline{s}$ suffix with singular verbs may be attributable to the context of learning and teaching. The ESL teacher may sometimes overemphasize the uses of $\underline{s}-1$ ess verbs, especially with pronouns like I, you and we. Similarly, the misuse of the $\underline{s}$ suffix with plural verbs may be due to the context of learning. The teacher may try hard to focus the learner's 
attention on the use of $\underline{s}$ with verbs when they follow singular subjects. These two possible explanations show how the context of learning and teaching may induce errors. Besides, they point to the difficulty of pinpointing the sources of errors. The fact that there may be more than one source at work does not negate the value of having a set of categories of sources that helps one to better understand second language acquisition.

\section{SUMMARY}

Interference from Arabic has been detected in a number of the identified errors. Other errors have been attributable to overgeneralization, ignorance of rule restrictions, incomplete rule application, curricula, and the learning/teaching context. A number of errors have been ascribed to more than one source. These multiple source errors pose an inevitable problem for researchers who try to compare and validate the findings of the different error analyses that focus on learners with the same NL background. The ratio of interlingual to intralingual errors was found to be $2.4: 1$. This ratio supports the first hypothesis, but it does not support the second hypothesis about interlingual errors being less frequent than intralingual ones in the writing of Arab students at this advanced level of ESL instruction.

In this chapter a selected sample of grammatical errors in sentence level, semantic and stylistic errors that ocdurred in the writings of Arab learners of English was analyzed. Errors have been identified, classified, and then explained in terms of the 
two major sources of errors: interlingual and intralingual.

With the recent emphasis on communicative language teaching (Savignon 1983, among others), second language researchers have shifted their focus from the classification and explanation of errors to the evaluation of errors in terms of their communicative effect or impact on native speakers of the language. Thus, the following chapter deals with the communicative effect of some grammatical and semantic errors that were detected in the compositions under investigation. 


\section{CHAPTER V \\ COMMUNICATIVE ERROR EVALUATION}

The study reported in this chapter evaluated the communicative effect of a selected sample of errors in written English made by native Arab learners. An attempt was made to address some of the methodological weaknesses that have characterized the majority of such studies to date. The purpose was twofold: 1) to investigate the extent to which judgments of intelligibility and acceptability differed among the groups of judges; 2) to investigate the extent to which error type (grammatical or semantic) affected the intelligibility and acceptability of the deviant passages. Table II, on the following page, shows the total weighted scores of the different types of errors on the two scales, intelligibility and acceptability.

Forty-five judges volunteered to take part in the study. They formed three different groups, 15 in each group. One group consisted of 15 students from different language backgrounds, including English, training to become ESL teachers in the future. The second group consisted of 15 American undergraduates enrolled in a writing course during winter Term 1988. The third group consisted of 15 Arab students enrolled at a university in oregon where the instruction and curricula are in English.

The error sample used in the questionnaire in this study consisted of 20 grammatically and 10 semantically deviant passages 
selected from the errors that occurred in the 30 compositions under investigation which were written by Arab ESL students. Grammatically deviant passages contained errors in word order, concord, verbs, spelling, and pronoun retention. Semantically deviant passages, on the other hand, consisted of errors in lexis and collocation. Stylistic errors were not included in the questionnaire because they occupy a large space. At least one paragraph should be presented to show one or two stylistic features. The deviant passages were edited so that each contained only one error, but the editing did not affect the general meaning of the passage. (Appendix $C$ presents a sample of the questionnaire).

TABLE II

TOTAL WEIGHTED SCORES PER CATEGORY

\begin{tabular}{|c|c|c|c|c|c|c|}
\hline \multirow{2}{*}{$\begin{array}{l}\text { ERROR } \\
\text { TYPE }\end{array}$} & \multicolumn{3}{|c|}{ INTELLIGIBILITY } & \multicolumn{3}{|c|}{ ACCEPTABILITY } \\
\hline & FRESHMEN & $\overline{A R A B}$ & TESL & FRESHMEN & ARAB & TESL \\
\hline Word Order & 249 & 268 & 261 & 208 & 218 & 206 \\
\hline Concora & 249 & 283 & 280 & 237 & 221 & 235 \\
\hline Verb & 251 & 263 & 271 & 177 & 198 & 214 \\
\hline Ret.Pronoun & 159 & 173 & 169 & 134 & 141 & 144 \\
\hline Spelling & 94 & 103 & 94 & 73 & 65 & 90 \\
\hline Lexis & 216 & 254 & 231 & 215 & 210 & 192 \\
\hline collocation & 180 & 217 & 193 & 165 & 187 & 140 \\
\hline GRAMMATICAL & $\frac{1002}{2}=501$ & $\frac{1090}{2}=545$ & $\frac{1075}{2}=538$ & $\frac{829}{2}=415$ & $\frac{843}{2}=422$ & $\frac{889}{2}=445$ \\
\hline SEMANTIC & 396 & 471 & 424 & 380 & 397 & 332 \\
\hline TOTAI & 897 & 1016 & 962 & 795 & 819 & 777 \\
\hline
\end{tabular}

NOTE: The higher the score, the more tolerant the group is to the erroneous passages presented in the questionnaire. 
The results of the total weighted scores of the questionnaire in Table II provide an answer to the question of which error type, grammatical or semantic, affected the judges' responses on the communicative effect of the deviant passages on the two scales, intelligibility and acceptability. The answers of each group of judges on each scale were counted and then multiplied by the number they chose on the 4-point scale. The results were added to arrive at the weighted scores for each error type within the two major categories of errors, i.e., grammatical and semantic. The scores for each category, grammatical and semantic, were added to arrive at a comparison of the total weighted scores for these two major categories. The total weighted scores of the grammatical errors are divided by two every time they are compared to the total weighted scores of the semantic errors because the questionnaire contained 20 grammatical errors and only 10 semantic ones. On the intelligibility scale, grammatically deviant passages were judged higher than semantically deviant ones; i.e., they were judged to be more intelligible by the three different groups of judges (Freshman, 501, Arab, 545, and TESL, 538). On the acceptability scale, grammatically deviant passages were also judged to be more acceptable than semantically deviant ones, (Freshman, 415, Arab, 422, TESL, 445).

Moreover, the results in Table II and Figure 1 show that the TESL group was more tolerant and accepting of both grammatical and semantic errors than the group of freshmen who are also native speakers of English. The total weighted score of the TESL group's 
judged intelligibility was 962, while that of the group of freshmen was 897 . The total weighted scores of the grammatical errors of the group of Arab judges were 545 on the intelligibility scale and 422 on the acceptability scale. Meanwhile, the total weighted scores of the semantic errors of the Arab group of judges were 471 on the intelligibility scale and 397 on the acceptability scales. Figure 1 shows the total weighted scores of the grammatical and semantic errors as evaluated by the three groups of judges on the two scales, intelligibility and acceptability. The higher the column, the more intelligible and acceptable the error type is to the group of judges.

FIGURE 1

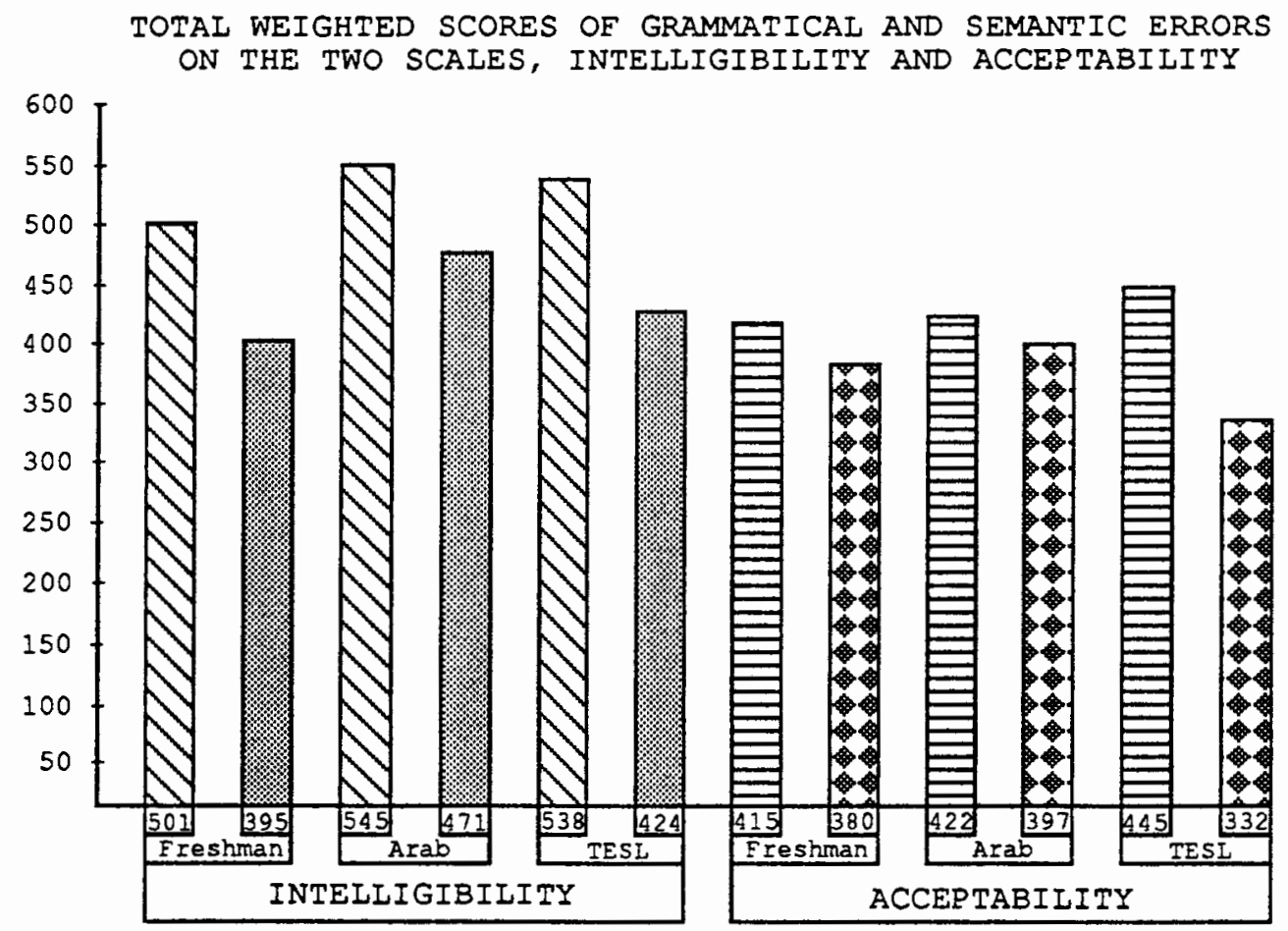

$\triangle$ Grammatical Intelligibility

Semantic Intelligibility Grammatical Acceptability

Semantic Acceptability 
Intelligibility was judged higher than acceptability in all different categories of types of errors. In other words, evaluations of intelligibility and evaluations of acceptability differed, with passages judged to be more intelligibile than acceptable. The total weighted scores of the TESL group's judged acceptability was 777 , while that of the group of freshmen was 795. Higher rating of the deviant passages on the intelligibility scale than on the acceptability scale shows that not every passage that is intelligible is judged acceptable by native speakers of the language.

Chi Square values were computed to determine whether there were significant differences among the three groups of judges in rating intelligibility and acceptability of grammatical and semantic errors. Table II presents these Chi square values.

TABLE III

CHI SQUARE FOR GRAMMATICAL VS. SEMANTIC ERRORS

\begin{tabular}{|c|c|c|c|c|}
\hline $\begin{array}{l}\text { Error } \\
\text { Types }\end{array}$ & Scales & $\begin{array}{c}\text { Freshmen } \\
\text { vs. } \\
\text { Arabs }\end{array}$ & $\begin{array}{c}\text { Freshmen } \\
\text { VS. } \\
\text { TESI Group }\end{array}$ & $\begin{array}{c}\text { Arabs } \\
\text { vs. } \\
\text { TESI Group }\end{array}$ \\
\hline Grammatical & $\begin{array}{l}\text { Intelligibility } \\
\text { Acceptability }\end{array}$ & $\begin{array}{l}23.70 * \\
1.02\end{array}$ & $\begin{array}{l}15.60 * \\
6.36\end{array}$ & $\begin{array}{l}1.54 \\
4.54\end{array}$ \\
\hline Semantic & $\begin{array}{l}\text { Intelligibility } \\
\text { Acceptability }\end{array}$ & $\begin{array}{l}15.60 * \\
1.12\end{array}$ & $\begin{array}{l}2.52 \\
7.73\end{array}$ & $\begin{array}{c}6.04 \\
12.10 \star\end{array}$ \\
\hline
\end{tabular}

degrees of freedom $=3$

CHI square Critical $=7.82$

* Significant at $P<.05$ 
There was significant disagreement on judged intelligibility of grammatical errors betwen the group of freshmen and the Arab group of judges: Chi square $=23.70, \mathrm{P}<.05$. The reason for this significant difference is that the responses of the group of freshmen on the scale of intelligibility centered around the first two points (choices $1,2=$ not intelligible), while those of the group of Arab judges centered around the last two points on the scale (choices $3,4=$ perfectly intelligible). (Appendix $D$ presents the total number of choices on the 4-point scale). The grammatical deviance in the passages affected the judgment of the group of freshmen on the intelligibility scale more than that of the group of the Arab judges on the same scale.

There was also a significant difference on judged intelligibility between the freshman group of judges and the group of TESL judges: Chi square $=15.60, \mathrm{p}<.05$. The responses of the group of TESL judges on the intelligibility scale were concentrated around choices 3 and 4; i.e., perfectly intelligible, whereas the TESL group's judgment on the intelligibility of the grammatically erroneous passages was apparently less affected by the deviance in the passages than was the freshman group's judgment.

However, differences between the Arab and TESL judges on intelligibility of grammatical errors were not significant: Chi Square $=1.54$, n.s. The disagreement on judged intelligibility of the semantically deviant passages was significant between the freshman group and the Arab group of judges: Chi square $=15.60$, P<.05. The judgment of the group of freshmen was affected by 
semantic errors more than the judgment of the Arab group on the same type of errors. The only significant disagreement on judged acceptability of the semantically deviant passages was between the group of Arab judges and the TESL group: Chi Square $=12.10$, $\mathrm{P}<.05$.

Chi Square values in Table IV for the intelligibility and acceptability measures of the specific types of grammatical and semantic errors show that there were significant differences in judged intelligibility and judged acceptability of six different types of errors among the three groups of judges, especially the TESL group and the freshman group of judges.

TABLE IV

CHI SQUARE VALUE FOR ALL TYPES OF ERRORS

\begin{tabular}{|c|c|c|c|c|}
\hline Error Type & $\begin{array}{c}\text { Scales } \\
\text { (Intelligibility } \\
\text { Acceptability) }\end{array}$ & $\begin{array}{c}\text { Freshmen } \\
\text { vs. } \\
\text { Arabs }\end{array}$ & $\begin{array}{c}\text { Freshmen } \\
\text { vS. } \\
\text { TESL Group }\end{array}$ & $\begin{array}{c}\text { Arabs } \\
\text { vs. } \\
\text { TESI Group }\end{array}$ \\
\hline Word Order & $\begin{array}{l}\text { INTELL. } \\
\text { ACCEPT. }\end{array}$ & $\begin{array}{l}3.33 \\
1.69\end{array}$ & $\begin{array}{l}2.20 \\
0.17\end{array}$ & $\begin{array}{l}1.14 \\
1.39\end{array}$ \\
\hline Concord & $\begin{array}{l}\text { INTELL. } \\
\text { ACCEPT. }\end{array}$ & $\begin{array}{l}14.80 * \\
3.31\end{array}$ & $\begin{array}{l}12.30 * \\
3.54\end{array}$ & $\begin{array}{l}1.00 \\
4.64\end{array}$ \\
\hline Verb & $\begin{array}{l}\text { INTELI. } \\
\text { ACCEPT. }\end{array}$ & $\begin{array}{l}1.84 \\
4.27\end{array}$ & $\begin{array}{c}4.39 \\
13.30 *\end{array}$ & $\begin{array}{l}1.47 \\
3.04\end{array}$ \\
\hline $\begin{array}{l}\text { Pronoun } \\
\text { Retention }\end{array}$ & $\begin{array}{l}\text { INTELI. } \\
\text { ACCEPT. }\end{array}$ & $\begin{array}{l}6.86 \\
1.40\end{array}$ & $\begin{array}{l}3.54 \\
3.04\end{array}$ & $\begin{array}{l}\text { ERROR } \\
0.00 \\
0.47\end{array}$ \\
\hline Spelling & $\begin{array}{l}\text { INTELL. } \\
\text { ACCEPT. }\end{array}$ & $\begin{array}{l}7.58 \\
2.09\end{array}$ & $\begin{array}{l}1.07 \\
5.18\end{array}$ & $\begin{array}{c}4.37 \\
10.70 *\end{array}$ \\
\hline Lexis & $\begin{array}{l}\text { INTELL. } \\
\text { ACCEPT. }\end{array}$ & $\begin{array}{l}10.30 \star \\
1.60\end{array}$ & $\begin{array}{c}4.15 \\
10.40 \star\end{array}$ & $\begin{array}{l}7.17 \\
4.77\end{array}$ \\
\hline collocation & $\begin{array}{l}\text { INTELL. } \\
\text { ACCEPT. }\end{array}$ & $\begin{array}{l}7.17 \\
3.52\end{array}$ & $\begin{array}{c}3.30 \\
10.20 *\end{array}$ & $\begin{array}{c}9.05 * \\
14.00 *\end{array}$ \\
\hline
\end{tabular}

Degrees of Freedom $=3$

CHI Square Critical $=7.82$

*Significant at $\mathrm{P}<.05$ 
Within the grammatical category of errors, the groups of freshmen and TESL judges showed significant difference in judged intelligibility of errors in concord: Chi square $=12.30, \mathrm{P}<.05$.

Table IV shows another significant difference in judged acceptability between the group of TESL judges and the freshman group of judges was in the area of verbs: CHI square $=13.30$, P<.05. Meanwhile, within the category of semantic errors, these two groups showed significant difference in judged acceptability of errors in lexis: $\mathrm{Chi}$ square $=10.40, \mathrm{P}<.05$, and collocation: Chi square $=10.20, \mathrm{p}<.05$. The fact that three of the $\mathrm{six}$ Chi Square values for acceptability of semantic errors were statistically significant, whereas only two of the ten CHI square values for grammatical errors were statistically significant supports the results in Tables II and III about semantic errors being judged as less acceptable than grammatical ones. There was also another significant disagreement between the group of Arab judges and that of TESOL judges in judged intelligibility: Chi square $=9.05$, P<.05, and judged acceptability: Chi Square $=14.00, P<.05$, of the semantically deviant passages.

\section{SUMMARY}

To sum up the results of the study reported in this chapter, there were statistically significant differences in native speakers' evaluations of the communicative effect of deviant passages. The group of TESL judges was more tolerant to and accepting of the deviant passages than the group of freshmen 
judges. This tolerance to and acceptance of errors among the TESL group might be due to the familiarity of the members of this group of judges with ESL students' performance, and to the training they receive to prepare them to become ESL teachers in the future. Semantically deviant passages were judged by all three groups of judges as less intelligible and acceptable than grammatically deviant ones. 
CHAPTER VI

PEDAGOGICAL IMPLICATIONS AND SUGGESTIONS

SUMMARY

The answer to the first question about the types of interand intralingual errors that are most frequently made by Arab students in the ESL upper intermediate and advanced levels is shown in Table I on page 31. The frequency count of errors shows that grammatical errors were more frequent in the compositions under analysis than were semantic errors, at a ratio of $7: 1$. This ratio supports the hypothesis that grammatical errors, both interand intralingual, are more frequent than semantic ones in the writing of Arab students in the intermediate and advanced ESL levels. The table also shows that errors due to interference from Arabic were more frequent than intralingual errors, at a ratio of 2.4:1. Of the types of grammatical errors, there were 62 errors in the use of English articles, and 59 errors in the use of prepositions; these were the highest error types according to the frequency count of errors.

Although the frequency count of errors showed that grammatical errors were more frequent than semantic errors, native speakers' evaluation of the communicative effect of errors showed that grammatical errors were considered more intelligible and acceptable than semantic ones (Tables II and III). Therefore, it 
is recommended that teachers be aware of the serious effect of semantic errors on communication. Teachers, on the other hand, should not minimize the seriousness of grammatical errors and the effect of interference on this type of errors.

The second hypothesis stated that interlingual errors are less frequent than intralingual ones in the writing of $A r a b$ students in the ESL intermediate and advanced levels. The results do not support this hypothesis. The ratio of interlingual to intralingual errors was found to be $2.4: 1$; i.e., almost three of every four errors were interference errors. This result supports the first hypothesis, but it does not support the second one.

The third hypothesis stated that semantic errors will be judged as more likely to affect communication than grammatical errors. The total weighted scores in Table II show that semantically deviant passages affected the native speakers' comprehension of the passages more than did grammatically deviant ones. Put differently, the results in Table II show that semantic errors were a more serious impediment to communication and less tolerated and accepted by native speakers than were grammatical errors. CHI Square values of the different types of grammatical and semantic errors show that there was significant disagreement between the group of TESL judges and the freshman group of judges on the judged intelligibility and judged acceptability of errors in concord, verbs, lexis and collocation. Therefore, this lack of agreement on the communicative effect of errors between the two groups of native speakers does not help ESL teachers and 
researchers establish a hierarchy of errors for purposes of error treatment and correction in the classroom (Hendrickson 1978). However, the results of the total weighted scores show that the TESL group was less affected by and more accepting to the deviant passages than the group of freshmen. This tolerance of errors by the TESI group might be due to the training the members of the TESL group receive to become ESI teachers in the future. Yet, the freshmen group's evaluation is significant for ESL teachers if the teachers were to qualify the students to interact successfully with different people in the community.

\section{CONCLUSION}

Based on the results of this study it is recommended that more time be given to writing classes so that the students could be drilled effectively in writing. One of the techniques that might help Arab students improve their writing skills and reduce the number of interference errors in their performance is sentence combining exercises. As pointed out by P.J. Angelis (1975:293) sentence combining exercises "have been shown to be helpful in developing writing skills for native and non-native speakers and can be incorporated directly into the overall program we are proposing." Sentence combining exercises can help alleviate the effect of interference from Arabic in the writing of Arab students in areas such as word order, sequence of tenses, repetition or omission of prepositions and connectives, omission of copula, redundancy in the use of pronouns, etc. 
Based on the findings of this thesis, it is recommended that semantic errors be given more attention in the ESL classroom since they are more likely to impede communication than grammatical errors. It is generally understood that when communicative competence is the goal of instruction, learner attention should be directed to semantic as well as grammatical features of the language.

This thesis is limited in the number of compositions used for analysis; only thirty compositions that were written by Arab ESL students were investigated. It is also limited in that it restricts itself to errors at the sentence level. Among the other types of errors in the writing of Arab ESL students that are worth investigating in future research are: stylistic errors, rhetorical errors due to first language interference (e.g., problems of prolixity and redundancy), and errors in the use of cohesive devices such as conjunction and reference. 


\section{BIBLIOGRAPHY}

Abboud, Peter (et al). 1975. Elementary Modern Standard Arabic: Part One. Ann Arbor. University of Michigan Press.

Alatis, J.E. 1968 (ed>). Contrastive Linguistics and Its Pedagogical Implications. Monograph Series on Language and Linguistics. No. 21, Washington, D.C.: Georgetown University Press.

Albrechtsen, Dorte, Birgit Henricksen, and Claus Faerch. 1980. Native Speaker Reactions to Learners' Spoken Interlanguage. Language Learning, 30(2):365-395.

Angelis, P.J. 1975. "Sentence Combining, Error Analysis and the Teaching of Writing." New Directions in Second Language Learning: Teaching Bilingual Education. Ed. Burt and Dulay. 292-299.

Arapoff, Nancy. 1968. "Writing: A Thinking Process." TESOL Quarterly. $11(4): 33-39$.

Burt, Marina K., and Carol Kiparsky. 1975. "Global and Local Mistakes." In New Frontiers in Second Language Learning, John H. Schumann and Nancy Stenson (Eds.). 71-30. Rowley, Massachusetts: Newbury House.

Burt, Marina K. 1975. "Error Analysis in the Adult EFL classroom." TESOL Quarterly 9 (1):53-63.

Carrol, John B. 1968. "Contrastive Analysis and Interference Theory", in Report of the Nineteenth Annual Round-Table Meeting on Linguistics and Language Studies. Georgetown University Press: washington, D.C., 1968, 113-121.

Chastain, Kenneth. 1980. "Native Speaker Reaction to InstructorIdentified Student Second-Language Errors." Modern Language Journal, 64(2):210-215.

Chomsky, N. 1965. Aspects of the Theory of Syntax. Cambridge, Mass.: MIT Press.

Corder, S.P. 1967. "The Significance of Learner's Error". IJAL $5: 161-170$.

Dulay, H. and Burt, M. 1974a. "Errors and Strategies in Child Second Language Acquisition." TESOL Quarterly 8:129-136.

Dulay, H. and Burt, M. 1974b. "You Can't Learn Without Goofing: An Analysis of Children's Second Language Errors," in J.C. Richards (ed.), Error Analysis. 
Eckman, Fred R. 1977. "Markedness and the Contrastive Analysis Hypothesis." Language Learning 27:315-330.

Ferguson, C.A. 1959. "Diglossia." Word 15:325-340.

Fries, C.C. 1945. Teaching and Learning English as a Foreign Language. Ann Arbor: University of Michigan Press.

Guntermann, Gail. 1978. "A Study of the Frequency and Communicative Effects of Error in Spanish." Modern Language Journal 62:245-253.

Haywood, J.A. and H.M. Nahmad. 1976. A New Arabic Grammar of The Written Language. Harvard University Press. Cambridge, Mass.

Hendrickson, James M. 1978. "Error Correction in Foreign Language Teaching: Recent Theory, Research, and Practice." Modern Language Journal. 62:387-398.

Jakobovits, L.A. 1969. "Second Language Learning and Transfer Theory." Language Learning 19:55-86.

Kambal, Mohamed Osman A. 1980. "An Analysis of Khartoum University Students' Composition Errors with Implications for Remedial English in the Context of Arabicization." Ph.D. dissertation, University of Texas at Austin.

Kaplan, Robert B. 1967. "Contrastive Rhetoric and the Teaching of Composition." TESOL Quarterly I (4).

1976. "A Further Note on Contrastive Rhetoric," Communication Quarterly, 24(2):12-19.

Kharma, Nayef. 1981. "Analys is of Errors Committed by Arab University Students in the Use of the English Definite/Indefinite Articles." IRAL 19:333-345.

Koch, Barbara J. 1983a. "Arabic Lexical Couplets and the Evolution of Synonymy." General Linguistics. 23:51-61.

1983b. "Presentation as Proof: the Language of Arabic Rhetoric." Anthropological Linguistics. 25: 47-60.

Lado, Robert. 1957. Linuistics Across Cultures. Ann Arbor: University of Michigan Press.

Mukattash, Lewis. 1981. "Wh-Questions in English: A Problem for Arab Students." IRAL 19. 4:317-332. 
Nickel, G. 1971. (ed.) Papers in Contrastive Linguistics. Cambridge, England: Cambridge University Press.

Panos, Karyn Thompson, et al. 1983. "The Least You Should Know about Arabic: Implications for the ESL Writing Instructor." TESOL Quarterly. $17,4: 609-623$.

Politzer, Robert L. 1978. "Errors of English Speakers of German as Perceived and Evaluated by German Natives." Modern Language Journal 62:253-261.

Richards, J.C. 1971. "A Non-Contrastive Approach to Error Analysis." English Language Teaching 25:205-219.

1974. "Error Analysis. Perspective on Second Language Acquisition." London: Longman.

Savignon, S. 1983. Communicative Competence: Theory and Classroom Practice. Reading, Mass.: Addison-Wesley.

Schachter, Jacqueline. 1974. "An Error in Error Analysis." Language Learning 24:205-214.

Scott,M.and G. Tucker. 1974. "Error Analysis and English Language Strategies of Arab Students." Language Learning $24: 69-98$.

Selinker, Larry. 1969. "Language Transfer." General Linguistics, $9: 67-92$.

1972. "Interlanguage." IRAL 10. 3:209-231.

Semaan, Khalil I. 1977. Arabic Phonetics. Ibn Sinā's Risālah, 2nd edition. Lahore, Pakistan.

Tomiyama, Machiko. 1980. "Grammatical Errors and Communication Breakdown." TESOL Quarterly 14(1):71-79.

Wardhaugh, Robert. 1970. "The Contrastive Analysis Hypothesis." TESOL Quarterly, 4, 2:123-130.

Whitman, R.L. and Jackson. 1972. "The Unpredictability of Contrastive Analysis". Language Learning 22. 1:19-41.

Willcot, Paul. 1972 "problems of Definiteness in the Written English of Arabic Speakers". English Language Teaching Journal 33. 1:67-73.

Wright, W. 1971. A Grammar of The Arabic Language. Third Edition. Cambridge University Press. 


\section{APPENDIX A}

Abbreviations

LI : Mother Tongue/Native Language

L2 : Second Language

EFL : English as a Foreign Language

ESL : English as a Second Language

CA : Contrastive Analysis

TL : Target Language

NL : Native Language

EA : Error Analysis

TWE : Test of Written English

TEFL : Teachers of English as a Eoreign Language Teaching of English as a Foreign Language

TESOL: Teaching of English to Speakers of Other Languages

TESL

Teachers of English as a Second Language Teaching of English as a Second Language 
APPENDIX B

Errors Due to NL Transfer

1. Grammatical Transfer

(1) They did not know how could they get out of this.

(2) Those subjects I was obliged to take them.

(3) I had five subjects which they are.

(4) That what I used to study.

(5) I do appreciate being here and proud of studying here.

(6) This all I study inside the class.

(7) I've learned much about treating with others.

(8) One builds the friendship.

(9) Behave in good way.

(10) It is very old room.

(11) I've learn about the childhood.

(12) It was very good aim.

(13) It was very interesting one.

2. Lexical Transfer

(1) They learnt the pupils how to behave.

(2) My lesson learn me many things.

(3) Books which have relations with my lessons.

(4) Say my opinion.

(5) The University has a dangerous and great letter.

3. Stylistic Transfer

(1) The way of teaching the subject and the lessons each book obtain has the main effect of such a course to be understood.

(2) Couragely with great confidence of yourself.

(3) I learned the spirit of team work and not to be selfish, but I must think of other people.

(4) A good topic sentence can tell about what the paragraph is speaking about, so my English language is better than it was, because in all periods and sometimes out of the class we speak English for practicing and to deal with it very well for all subjects we are taking it in the University.

(5) According to my English class I really feel now that it was very useful for me, in spite of the difficulties, and the hard assignments that my teacher used to give me with my class, and really think that it was the proper 
way in which I and my class could learn anything, because of that I am really appreciate my teacher who was very hard with me and with all my class, because unless that, we could not learn anything.

\section{Errors Due to Overgeneralization}

(1) I don't know when does the holiday start.

(2) There is six lights in it.

(3) When the student finish school.

(4) John do not believe about ...

(5) A creature who have the courage.

(6) He want to . .

(7) He use it to shoot.

(8) The principles of the University is ...

(10) Most of them shows ...

(11) Poor people who suffers...

\section{Errors Due to Ignorance of Rule Restrictions}

(1) He knew the general won't let him go.

(2) I never thought I will be ...

(3) I had two courses that are...

(4) If anything was not clear, I must ask the teacher.

(5) I also learned how to overgeneralize the things that I want to do.

(6) I knew people and I've heard a lot of talking.

(7) Perhaps I did something or say something that I regret it afterwards.

(8) I learned many things when I enter oregon State University.

(9) They graduate after they got their education.

(10) We also meet new faces and making relationship with them.

(11) The teacher explains the lessons which are very useful.

(12) I didn't expect that I am going to be late. 


\section{APPENDIX C \\ REACTION TO ESL STUDENTS' WRITING}

The following passages were produced in compositions written by English as a second Language students. The goal of this questionnaire is to study the communicative effect of these passages on native speakers of English.

(Thanks for your cooperation and contribution to the study.)

INSTRUCTIONS

1. Read the passages carefully and mark each one of them on the two scales written on the right side of this paper. The scales are intelligibility and acceptabiity. Each scale consists of 4 points with number "l" being least intelligible or acceptable; number "4" on the scale means highly intelligible or acceptable.

Notes:

1) Intellibibility means your understanding of the meaning of the passage.

2) Acceptabiity refers to the degree to which you think each passage violates the English language norms.

Example:

So far the change was marvelous, yet people misunderstood what did

it mean to be civilized.
Intelligible

Low High

1234
Acceptable

Low High

$\begin{array}{llll}1 & 2 & 3 & 4\end{array}$

1. A lot of new things I've

learned from my parents.

1234

$\begin{array}{llll}1 & 2 & 3 & 4\end{array}$

2. Learning about life is something everyone have to do.

3. I think if I have too much monye, my problems will increase.

4. I am used to have girls as my classmates in college. 
Intelligible

Low High
Acceptable

Low High

5. I've chosen to study in

the United States not for

only a good education.

1234

1234

6. My family, on the other

hand, belongs to a past race.

$123 \quad 4$

1234

7. I go to the theater

seldom nowadays.

1234

$\begin{array}{llll}1 & 2 & 3 & 4\end{array}$

8. The boxes were standing

on one line and there was

spaces between them.

1234

1234

9. They ate him fleshly and

threw him boney.

1234

1234

10. How can we cwalife the teachers to help improve

the educational system?

$123 \quad 4$

1234

11. Many people were killed

in the event between the

two cars.

12334

12234

12. At the beginning I didn't

know what was I going to study

at the University.

1234

12334

13. Let each man decides

for himself.

1234

1234

14. The teacher came to the class and his condition's tongue says he will give us a quiz.

15. Only once he has done such a thing.

16. He try to make himself busy.

17. These teachers don't know

what to do when we do mistakes.

18. People who prefer their jobs

to doing activities, probably

they enjoy or like their jobs. 
Intelligible

Low High
Acceptable Low High

19. The new university in Oman has a great letter. It provides different educational programs.

20. We have good professors.

This helps us to drink knowledge and experience from them.

21. Most people believes that their job is the most important activity in their life.

22. The exercises which I do them before any game keep me strong.

23. How can my parents learn me how to use the computer while they themselves don't know how to use it?

24. Everyone sleeps on the side which rests him.

25. I drove the car between the boxes according to the rules my brother teached me.

26. I spent the day thinking about the present my father had promist me.

27. When my friends explained to me the immigration rules I began to walk on the rules.

28. The doctor who working on his research enjoys the research more than anything else.

29. These foreign teachers did not know how to learn the students how to behave according to the Arabic culture.

30. I usually quit seeing T.V. during final exams. 


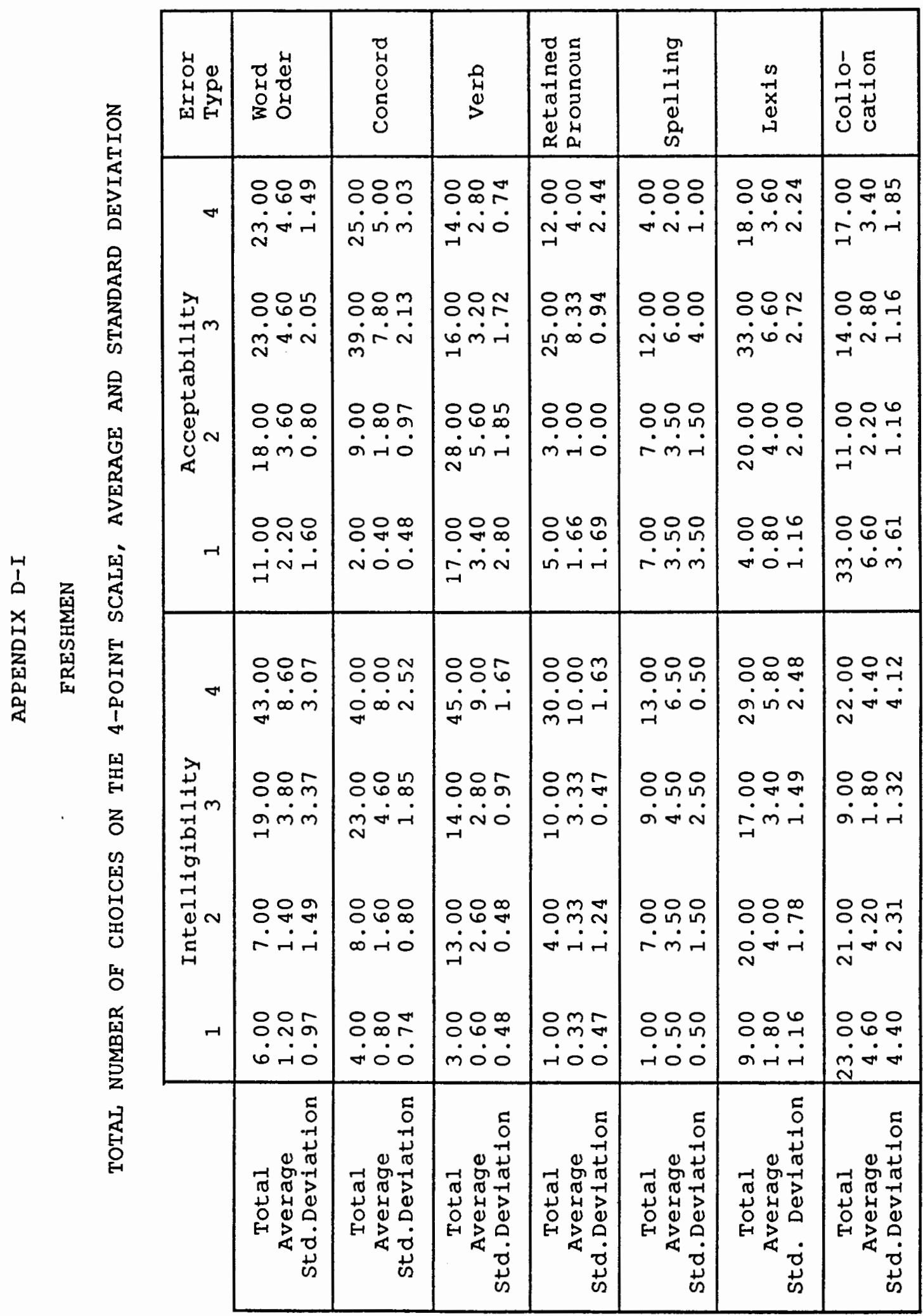




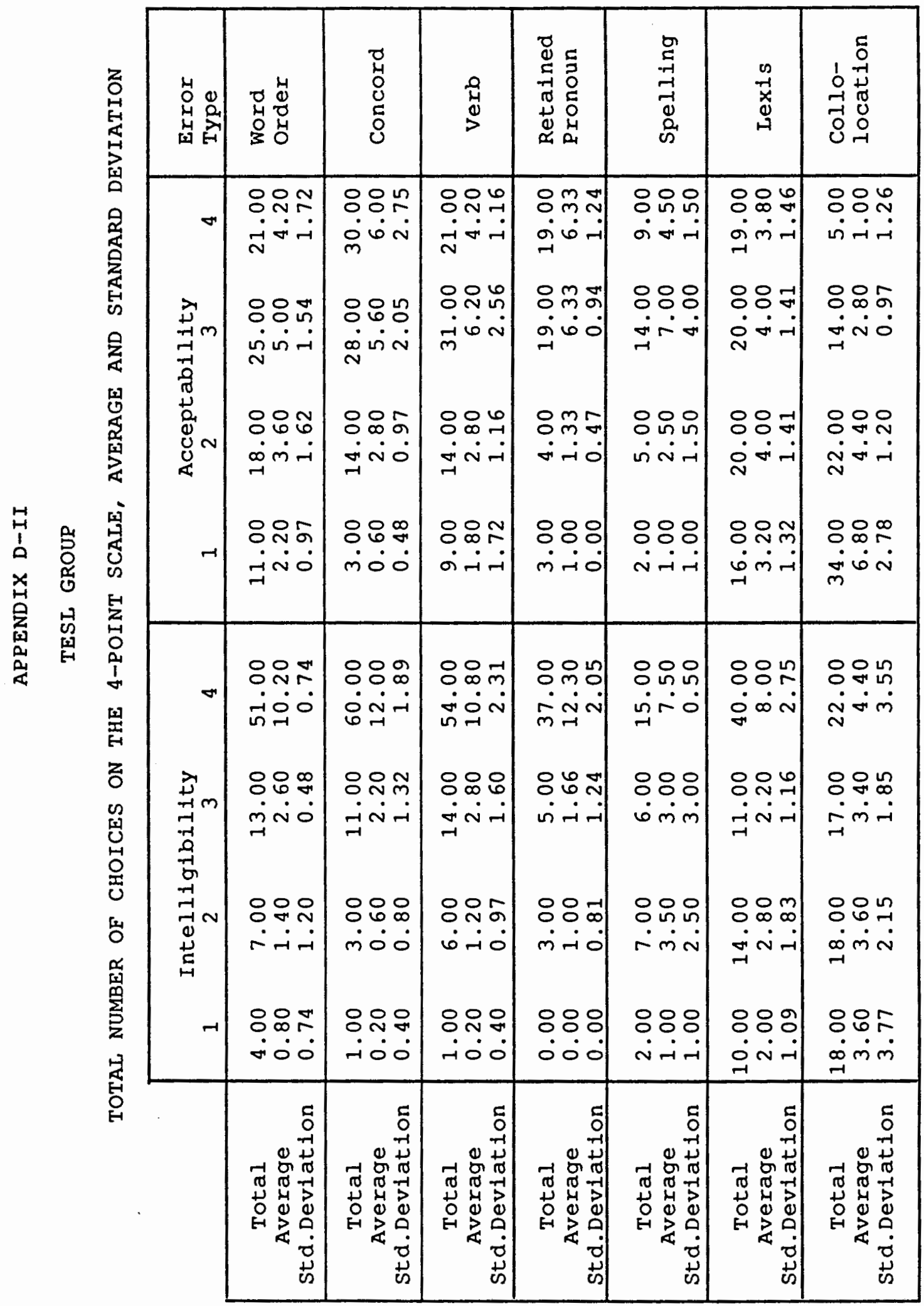




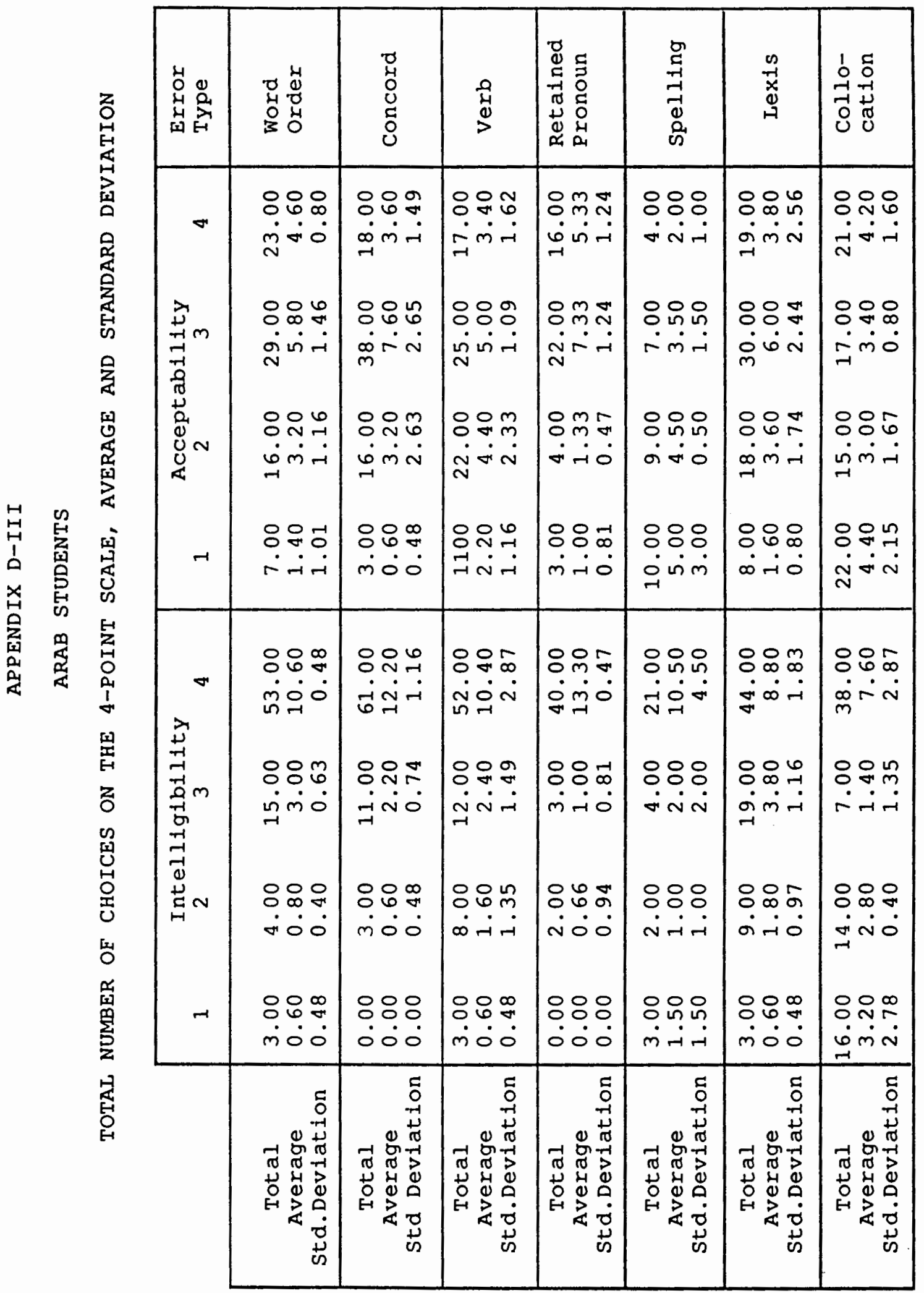

